Article

\title{
Vocational Education and Employment: Explaining Cohort Variations in Life Course Patterns
}

\author{
Fabian Kratz ${ }^{1}$, Alexander Patzina ${ }^{2, *}$, Corinna Kleinert ${ }^{3,4}$ and Hans Dietrich ${ }^{2}$ \\ ${ }^{1}$ Sociology Department, University of Munich, 80539 Munich, Germany; E-Mail: fabian.kratz@soziologie.uni-muenchen.de \\ 2 IAB-Institute for Employment Research, 90478 Nuremberg, Germany; E-Mails: alexander.patzina@iab.de (A.P.), \\ hans.dietrich@iab.de (H.D.) \\ ${ }^{3}$ LIfBi-Leibniz Institute for Educational Trajectories, 96047 Bamberg, Germany; E-Mail: corinna.kleinert@lifbi.de \\ ${ }^{4}$ Sociology Department, University of Bamberg, 96047 Bamberg, Germany \\ * Corresponding author
}

Submitted: 28 February 2019 | Accepted: 15 July 2019 | Published: 5 September 2019

\begin{abstract}
A stylized finding on returns to vocational education is that vocational compared to general education generates a differential life course pattern of employability: while vocational education guarantees smooth transitions into the labour market and thus generates initial advantages, these erode with increasing age, leading to late-life reversals in employment chances. We contribute to this research by assessing cohort variations in life-cycle patterns and distinguishing two explanations for late-life reversals in employment chances. The adaptability argument states that this phenomenon is due to the lower adaptability and occupational flexibility of those with vocational education. In contrast, the health argument states that vocational education leads to physically more demanding occupations, faster health deterioration, and, thus, lower employability in later life. Using data from the German Socio-Economic Panel, we employ non-parametric state probability analysis to assess cohort variations in employment patterns, and mediation analysis to assess how much of the late-life reversal of employment patterns is due to a faster health deterioration among the vocationally educated. Results show that the early life advantage of vocational education increases across cohorts. Furthermore, those with vocational education exhibit faster health deterioration, and a small part of the late-life employment disadvantage of this group works through lower levels of health after midlife.
\end{abstract}

\section{Keywords}

employment; Germany; life course methods; multi-cohort panel data; vocational education

\section{Issue}

This article is part of the issue "Types of Education, Achievement and Labour Market Integration over the Life Course", edited by Irene Kriesi (Swiss Federal Institute for Vocational Education and Training, Switzerland) and Juerg Schweri (Swiss Federal Institute for Vocational Education and Training, Switzerland).

(C) 2019 by the authors; licensee Cogitatio (Lisbon, Portugal). This article is licensed under a Creative Commons Attribution 4.0 International License (CC BY).

\section{Introduction}

From a human capital perspective, different educational programmes and fields of study provide not only a particular level of proficiency (vertical education dimension), but also a unique mix of general, field, occupational, and firm-specific skills (horizontal education dimension). Focusing on such horizontal differences, a study by Hanushek, Schwerdt, Woessmann and Zhang
(2017) has recently triggered an intense debate on the lifetime returns to general versus vocational education. The authors assume that vocational education generates a differential life course pattern of employability compared to general education. Their results indicate that vocational education provides smooth transitions into the labour market. However, as individuals grow older, this initial advantage erodes and even leads to a disadvantage at older ages. Several replication studies drawing 
on internationally comparative cross-sectional data support the general pattern of a trade-off in returns over the life course, although their conclusions regarding country differences are mixed (Forster, Bol, \& van de Werfhorst, 2016; Hampf \& Woessmann, 2017; Lavrijsen \& Nicaise, 2017). Studies devoted to only one country find large initial employment benefits of vocational education that later morph into marginal disadvantages before retirement in the Netherlands (Forster \& Bol, 2018), no tradeoff with regard to employment prospects in Switzerland (Korber \& Oesch, 2019), or only for the lesser-educated in the UK (Brunello \& Rocco, 2017).

While several of the above-mentioned studies assess differences in life cycle patterns from an international perspective, differences within countries, in particular across cohorts, are barely understood. This lack of research is surprising, as the assessment of cohort variations of inequality-generating mechanisms lies at the very heart of sociological research (Ryder, 1965). As with country-specific differences, cohort-specific differences may well result in different life course employment patterns. Cohort-specific structural effects provide the boundary conditions under which life-cycle employment patterns are generated. Consequently, the assessment of cohort variations in life cycle patterns emerges as an important research field in the social sciences (see, e.g., Leopold \& Leopold, 2018; Manzoni, Härkönen, \& Mayer, 2014). Thus, as a first important contribution to the literature, this study dedicates itself to a systematic assessment of cohort variations in life cycle employment patterns between those with general and vocational education.

In addition to the assessment of cohort variations, this study aims to contribute to the literature by distinguishing theoretical explanations that may account for the trade-off in returns over the life course. The literature presents two conflicting explanations (Hanushek et al., 2017): the adaptability argument and the health argument, whereas the former is clearly the most prominent explanation. According to this argument, vocational education provides mainly occupation-specific skills, thus fostering smooth transitions into the labour market. However, as workers age, this advantage erodes as specific skills lead to lower adaptability and occupational flexibility, particularly in labour markets characterized by technological change. In contrast, the health argument states that vocational education leads to physically more demanding occupations that lead to a faster health decline, explaining lower employability at older ages.

On the one hand, the assessment of such health differences between vocationally and generally educated over the life course constitutes a very instructive research question in its own right. Health differences, the most important predictor of subjective well-being, constitute an important dimension of social inequality. On the other hand, such increasing health differences over the life course may well be an intervening mediating mechanism that explains the late-life employment disadvantage of those with vocational education. Therefore, this study aims to make two further important contributions to the literature. First, we deliver a systematic assessment of how the health of both groups evolves over the life course. Second, we scrutinize health differences as an intervening mediating mechanism that explains the late-life employment disadvantage of vocational education.

To assess cohort variations in life cycle patterns as well as the mediating role of health differences, longrunning multi-cohort panel data from a country in which vocational education plays a prominent role is necessary. Fortunately, the German Socio Economic Panel (GSOEP) delivers data meeting these requirements. As Hanushek et al. (2017) argue, Germany is one of the most instructive countries for the assessment of returns to vocational education as it is the largest nation with a dominantly company-based vocational training system. The authors posit that in such countries, the late-life tradeoff in employment patterns should be most pronounced. In short, this study uses long-running multi-cohort panel data from the most populous country with a dual training system to assess (1) cohort variations in life cycle patterns between those with general and vocationally education (2) health differences between these two groups, and (3) the mediating role of health differences in explaining late-life employment differences.

\section{Literature Review}

As part of a literature review, we found ten studies that consider the relation between vocational and general education on employment outcomes. Those that do not focus on employment probabilities but rather on other outcomes (e.g., Cörvers, Heijke, Kriechel, \& Pfeifer, 2011; Golsteyn \& Stenberg, 2017; Verhaest, Lavrijsen, van Trier, Nicaise, \& Omey, 2018) have been excluded. Cörvers et al. (2011) focus on hourly wages, Golsteyn and Stenberg (2017) on annual labour earnings, while Verhaest et al. (2018) assess educational and skill mismatch. As vocational education typically assures job security and smooth transitions into the labour market but is generally related to less prestigious jobs with relatively low earnings (Shavit \& Müller, 2000; Lavrijsen \& Nicaise, 2017), educational gradients in different outcomes (e.g. employment opportunities, skill mismatch, wages) stem from different mechanisms. Therefore, we focus only on studies that consider employment probabilities as outcome. Table 1 lists the remaining seven studies.

Of the seven currently available studies assessing the impact of vocational versus general education on employment chances, five rely on cross-sectional data. Brunello and Rocco (2017) and Korber and Oesch (2019) are the only studies that implement analyses of panel data. While the former focus on two cohorts (birth cohorts 1958 and 1970), Korber and Oesch (2019) use two multi-cohort panel studies from Switzerland.

Studies relying on cross-sectional data observe current employment chances of different cohorts at differ- 
Table 1. State of research, data, and method.

\begin{tabular}{|c|c|c|c|c|}
\hline Study & Data set & Years & Method & Classification \\
\hline $\begin{array}{l}\text { Brunello and } \\
\text { Rocco (2017) }\end{array}$ & $\begin{array}{l}\text { National Child Development } \\
\text { Survey (NCDS), British } \\
\text { Cohort Survey (BCS) }\end{array}$ & 1981, 2000 & $\begin{array}{l}\text { Simulations (based } \\
\text { on age dummies) }\end{array}$ & $\begin{array}{l}\text { Two cohorts (born } \\
1958 \text { and 1970) } \\
\text { panel study }\end{array}$ \\
\hline $\begin{array}{l}\text { Forster and } \\
\text { Bol (2018) }\end{array}$ & $\begin{array}{l}\text { Dutch Labor Force } \\
\text { Survey (EBB) }\end{array}$ & 2010-2012 & $\begin{array}{l}\text { Linear probability model } \\
\left(\text { age }+ \text { age }^{2}+\text { age }^{3}+\text { age }^{4}\right)\end{array}$ & $\begin{array}{l}\text { Cross-sectional } \\
\text { study }\end{array}$ \\
\hline Forster et al. (2016) & $\begin{array}{l}\text { Programme for the } \\
\text { International Assessment of } \\
\text { Adult Competencies (PIAAC) }\end{array}$ & 2012 & $\begin{array}{l}\text { Logistic regression, } \\
\left(\text { age }+ \text { age }^{2}\right)\end{array}$ & $\begin{array}{l}\text { International cross- } \\
\text { sectional study }\end{array}$ \\
\hline $\begin{array}{l}\text { Hampf and } \\
\text { Woessmann (2017) }\end{array}$ & PIAAC & 2012 & $\begin{array}{l}\text { Linear probability model } \\
\left(\text { age }+ \text { age }^{2}\right)\end{array}$ & $\begin{array}{l}\text { International cross- } \\
\text { sectional study }\end{array}$ \\
\hline $\begin{array}{l}\text { Hanushek } \\
\text { et al. (2017) }\end{array}$ & $\begin{array}{l}\text { International Adult Literacy } \\
\text { Survey (IALS), German } \\
\text { Microcensus (MZ), Australian } \\
\text { Administrative Data }\end{array}$ & 1994-1998 & $\begin{array}{l}\text { Linear probability model + } \\
\text { propensity score matching }\end{array}$ & $\begin{array}{l}\text { International cross- } \\
\text { sectional study }+ \\
\text { German and Austrian } \\
\text { register data }\end{array}$ \\
\hline $\begin{array}{l}\text { Korber and } \\
\text { Oesch (2019) }\end{array}$ & $\begin{array}{l}\text { Swiss Labor Force Survey } \\
\text { (SLFS), Swiss Household } \\
\text { Panel (SHP) }\end{array}$ & $\begin{array}{l}\text { 1991-2014, } \\
\text { 1999-2013 }\end{array}$ & $\begin{array}{l}\text { Linear probability model } \\
\left(\text { age }+ \text { age }^{2}+\text { age }^{3}+\text { age }^{4}\right)\end{array}$ & $\begin{array}{l}\text { Multi-cohort } \\
\text { panel study }\end{array}$ \\
\hline $\begin{array}{l}\text { Lavrijsen and } \\
\text { Nicaise (2017) }\end{array}$ & PIAAC & 2012 & $\begin{array}{l}\text { Logistic regression } \\
\left(\text { experience }+ \text { experience }^{2}\right)\end{array}$ & $\begin{array}{l}\text { International cross- } \\
\text { sectional study }\end{array}$ \\
\hline
\end{tabular}

ent ages in order to construct artificial lifetime employment patterns. As individuals from a given birth year (cohort) are observed at one time point (period) and one age, scholars cannot separate age from cohort or period effects. Thus, such analyses must assume that there are no cohort effects (i.e., no cohort properties that relate to the ratio of general versus vocational education and employment opportunities) as well as no period effects (i.e., no business cycle effects in the observation year that affect the employment chances of general versus vocational education differently).

Studies relying on single cohort panel data observe current employment chances of one cohort at different ages and different observational time points. As individuals from one cohort grow older over the observational period, scholars cannot separate age from period effects, and must therefore assume that there is no significant bias due to business cycles.

Even when using multi-cohort panel data, researchers aiming to estimate life cycle employment patterns face the challenge of disentangling age effects and cohort effects, as well as period effects: age, period, and cohort (APC) are linearly dependent (age = period-cohort). As a result, estimating age effects and simultaneously controlling for cohort and period effects is not possible without identifying restrictions. Recent studies drawing on simulation exercises (Bell \& Jones, 2014a, 2014b, 2015; Luo, 2013) and mathematical proofs (Luo, Hodges, Winship, \& Powers, 2016; Pelzer, te Grotenhuis, Eisinga, \& Schmidt-Catran, 2015) demonstrate that purely statistical solutions to the APC problem fail because the confounding lies in the very nature of the linear dependency between APC. Therefore, several scholars agree that instead of trying to solve the APC problem by purely statistical constraints, scholars must employ solid theory and external information to choose an identification restriction (Bell \& Jones, 2015; Chauvel \& Schröder, 2015; Fienberg, 2013; Glenn, 2005; Heckman \& Robb, 1985; Rodgers, 1982).

If theoretical reasoning helps to identify explicitly measured macro variables that bring about period or cohort effects, scholars can include these variables in the model, thereby capturing either period or cohort effects (Heckman \& Robb, 1985). This identification restriction rests on the assumption that theory-guided variables can approximate period or cohort effects (Smith, Mason, \& Fienberg, 1982). While labour market research provides both theory and empirical evidence for macro-level variables that may bring about period effects impacting labour market returns over the entire employment career (unemployment rates, wage rates and GDP growth), rich empirical evidence for potential variables that may form cohort effects is missing. Using multi-cohort panel data while employing a theory-guided restriction for period effects (i.e., capturing period effects by explicitly measured macro variables) and controlling for cohort effects with dummy variables appears to be the most convenient way to avoid the age-period-cohort conundrum (Kratz \& Brüderl, 2017).

Cohort effects not only constitute a potential threat to valid conclusions about age effects, but cohorts also form the boundary conditions under which social processes function (Mannheim, 1928; Ryder, 1965). Thus, even an approach that accounts for cohort effects can- 
not rule out cohort variations in life cycle patterns. For this reason, scholars must assess such cohort variations in a further step, as it is only sensible to make inferences about life cycle patterns in the absence of cohort variations. If any are present, life courses should be assessed with respect to a specific cohort. If effects are simply averaged over cohorts, they mask important information about the social processes and mechanisms that bring about differences in life cycle patterns. Therefore, the estimation of cohort variations in life cycle patterns is not merely a methodological objective but is essential to uncovering the explanandum researchers aim to explain. Therefore, assessing cohort variations in life cycle patterns serves not only to investigate whether cohort interactions may be omitted, but may also provide grounds for theorizing under which temporal circumstances which social processes can be expected.

\section{Research Gap and Research Plan}

To advance the current state of research, the present study delivers an in-depth, multi-variable description of how to uncover changes in life cycle patterns across cohorts. In doing so, this study uses a theory-guided restriction to capture period effects when estimating cohort variations in life cycle patterns. In addition, we estimate the age effect non-parametrically, thereby not predetermining our results by assuming a particular age trajectory. As a result, this approach, compared to the current state of research, provides a better approximation of the complexity of human life courses. We are able to illustrate that a non-parametric approach is particularly important when investigating gender differences in employment patterns.

Furthermore, the late-life reversal of employment patterns between the generally and the vocationally educated may be due to different mechanisms. The main argument provided in previous literature is that the advantage of vocational education erodes with increasing age as specific skills lead to a reduction in adaptability and occupational flexibility in labour markets characterized by technological change. An alternative explanation for this phenomenon may be a faster health deterioration among those with a vocational background that leads to a faster decrease in employability (Hanushek et al., 2017). From this perspective, vocational education leads to physically more demanding jobs, especially among men. This higher physical burden, in turn, leads to a faster health deterioration, which results in a higher probability of labour force dropout.

To distinguish between these explanations, we employ mediation analysis (VanderWeele, 2015), which allows us to define and test total, direct, as well as indirect effects. As health measures are available in the GSOEP data, we are able to test whether there are significant indirect effects of general versus vocational education on employability that work through health. As neither education-specific measures of adaptability nor occupa- tional flexibility are available, the remaining direct effect must be interpreted as a result of these mechanisms. If there is no indirect effect of vocational education on late-life employment through health, this pattern may arise either because vocational education does not affect health, or because health does not affect employment. Therefore, to further understand the mediating role of health, we also provide evidence on the impact of vocational education on health over the life course. This mediation approach allows us to test and potentially rule out health as an alternative explanation for the late-life reversal of employability patterns.

\section{Data and Methods}

\subsection{Sample}

Our analyses rely on data from all available subsamples of the German Socio-Economic Panel (GSOEP) version 32 from 1984 to 2015 (for more details on the data see Goebel et al., 2019; Haisken-DeNew \& Frick, 2005). We exclude respondents who did not complete lower secondary education, as well as those who immigrated to Germany at or after age 14 . We further restrict the life courses under observation from 18-65 and exclude person-years when respondents are in education as well as before acquiring a final educational degree.

In sum, the sample for the analysis of gender and cohort variations in life cycle patterns (sample 1) contains 44,502 persons born between 1919 and 1998 with a total of 332,537 person-years (see notes of Figure 4 and Figure 5 for cohort-specific numbers). In order to test health as a mediating mechanism, we further restrict the sample as important health indicators are not available for the years 1990 and 1993 (sample 2). This restriction results in 43,106 persons and 309,769 person-years (for distribution of variables, see Table A1 in the Appendix).

\subsection{Variables}

\subsubsection{Vocational versus General Education}

From a human capital perspective, different educational programmes and fields of study provide not only a unique mix of general, field, occupation, and firmspecific skills (horizontal dimension), but also a particular level of proficiency (vertical dimension). Accordingly, a higher skill level should generate higher productivity, which corresponds to better employment chances. Testing the hypothesis of differential life-course returns to specific versus general skills therefore requires a contrast of these two types of skills at comparable skill levels.

In multi-country comparisons (e.g., Forster et al., 2016; Hanushek et al., 2017) researchers had to rely on rough international classifications such as ISCED levels and fields of study, which often do not adequately take country-specific peculiarities into account. As a result, these studies were only able to distinguish broad educa- 
tional levels (secondary versus tertiary) and formal programme type.

In Germany, vocational education and training is the prominent form of post-school education for students from lower and mid-level secondary schools (Hauptschulen and Realschulen), while graduates from upper secondary schools (Gymnasien) normally continue their studies in institutions of higher education, which are usually regarded as providers of general skills. Therefore, at each school level functional equivalents for vocational and general education are rare. To overcome potential singularities a detailed distinction of vocational and general education at each specific skill level is necessary.

The educational indicators defined here account for this institutional peculiarity and go beyond previous research in two respects. First, we build a more finegrained education variable with four values: lower secondary, upper secondary, post-secondary/lower tertiary, and higher tertiary education. Second, we distinguish between general and vocational programmes by using detailed information on the formal programme type in the German educational system, as well as considering double qualifications, particularly in the form of vocational education with higher education. As dealing with such double qualifications is not straightforward, we conduct several auxiliary analyses. These show that the lion's share of individuals with both qualifications first attained a vocational degree and later a general degree. We therefore consider the later educational attainment endogenous to the first (vocational education + further education that resulted in a general degree), resulting in double qualifications classified as vocational (for a more detailed overview and distribution of categories, see Tables A2 and A3 in the Appendix). To shed further light on the patterns of those with double qualifications, we compare this group with both the vocationally and generally educated in the robustness section.

\subsubsection{Control Variables}

In each analytical step, we include a vector $X_{i t}$ to capture both time-constant and time-variant individual-specific control variables (i.e., gender, nationality, an indicator for living in West Germany, an indicator for at least one parent with a university degree, highest educational level obtained). Further, to account for period effects, every model includes a vector $P_{t}$ comprising time-variant period measures (i.e., unemployment rate, GDP growth, wage rate, crisis dummy, year of Hartz reforms, i.e., cuttings of unemployment benefits). To account for cohort fluctuations, we include the vector $C_{i}$, which represents cohort dummies.

\subsubsection{Mediators}

To investigate a potential indirect effect explaining employment differences between vocationally and generally educated at later life course stages, we opera- tionalise health with nights spent in hospital in one (the last) survey wave, doctor visits in one (the last) survey wave, disability status, and health satisfaction.

\subsection{Methods}

The empirical analysis proceeds in several steps. First, we estimate gender-specific non-parametric state probability models with interactions of education type by age to allow for age variations in the effect of vocational versus general education on employment probabilities. Employing a non-parametric approach is important because such an estimator allows capturing the complexity of individuals' employment trajectories (Brüderl, Kratz, \& Bauer, 2018). Second, we estimate different health trajectories by vocational versus general education. Third, we estimate age-specific decomposition models. We specify the following models:

$$
\begin{aligned}
E m p_{i t}= & \alpha+\beta V o c_{i}+\gamma_{n} \sum_{n=2}^{47} A e_{n, i t} \\
& +\delta_{n}\left(\operatorname{Voc}_{i} \times \sum_{n=2}^{47} A g e_{n, i t}\right)+\lambda^{\prime} X_{i t}+\pi^{\prime} P_{t} \\
& +\tau_{i} C_{i}+\varepsilon_{i t} \\
\text { Health }_{i t}= & \alpha+\beta \operatorname{Voc}_{i}+\gamma_{n} \sum_{n=2}^{47} A g e_{n, i t} \\
& +\delta_{n}\left(\operatorname{Voc}_{i} \times \sum_{n=2}^{47} A g e_{n, i t}\right)+\lambda^{\prime} X_{i t}+\pi^{\prime} P_{t} \\
& +\tau_{i} C_{i}+\varepsilon_{i t}
\end{aligned}
$$

In model $1, E m p_{i t}$ represents the probability of being employed for individual $i$ at time $t$. In model 2, we use health satisfaction as a compound measure to capture both physical and mental dimensions of health. In both models, $\sum_{n=2}^{47} A g e_{n, i t}$ is a set of 46 dummy variables capturing age-related employment probabilities (model 1) and health differences (model 2) from age 18 to 65 (reference: age 18). $V o c_{i}$ is a binary variable, which is 1 for vocational education and 0 for general education. To allow for age variations in the effect of vocational education, we interact $V o c_{i}$ with age. The gender-specific models adjust for individual confounders $\left(X_{i}\right)$, period $\left(P_{t}\right)$, and cohort effects $\left(C_{i}\right)$. The cohort-specific models also use the same set of individual confounders and period measures.

We assess the mediating role of health in explaining lower employment probabilities of those with vocational education at older ages. For this assessment, we restrict the sample to individuals older than 54 and younger than 66 and run 11 age-specific KHB decomposition models. This type of model is a convenient mediation/decomposition method for binary dependent variables (Karlson \& Holm, 2011; Karlson, Holm, \& Breen, 2012; Kohler, Karlson, \& Holm, 2011). In such mod- 
els with non-linear dependent variables, researchers must distinguish the indirect effect-the percentage mediated-from a change in the explanatory variable of interest resulting from rescaling. In distinguishing mediation from rescaling, the KHB method solves this rescaling problem and performs as least as good as other methods when the dependent variable is binary (Linden \& Karlson, 2013). We compare the age-specific coefficient of vocational education of a full model $\beta_{F}$ that includes health estimates:

$$
\begin{aligned}
E p_{i t}= & \alpha+\beta_{F} \text { Voc }_{i}+\gamma^{\prime} \text { Health }_{i}+\lambda^{\prime} X_{i}+\pi^{\prime} P_{t} \\
& +\tau_{i} C_{i}+\varepsilon_{i t} \quad \text { if age } i \in[55,65]
\end{aligned}
$$

with the age-specific coefficient of vocational education of a reduced model $\beta_{R}$ that does not include such health estimates:

$$
\begin{aligned}
E m p_{i t}= & \alpha+\beta_{R} V o c_{i}+\lambda^{\prime} X_{i}+\pi^{\prime} P_{t} \\
& +\tau_{i} C_{i}+\varepsilon_{i t} \quad \text { if age } i \in[55,65]
\end{aligned}
$$

We estimate 11 age-specific full and reduced models starting from 55 and ending with 65 years of age. To test the significance of this indirect effect, the KHB method employs the delta method (Kohler et al., 2011, p. 424; Sobel, 1982). Figure 1 shows the un-confounding assumptions of our empirical analyses. The total effect of vocational education on employment probabilities is identified if there are no unmeasured confounders between vocational education and the probability of being employed (Confounder 1). The total effect of vocational education on health (Path a) is identified if there are no unmeasured confounders between vocational education and health (Confounder 3 ). The direct effect of vocational education on employment, net of health (Path c), and the indirect effect of vocational education through health, are identified if there are no unmeasured confounders between vocational education and employment (Confounder 1), no unmeasured confounders between health and employment (Confounder 2) and no unmeasured confounders between vocational education and health (Confounder 3, see also VanderWeele, 2015).

\section{Results}

\subsection{Gender Variations in Life Cycle Patterns}

In this section, we assess gender variations in cohort averaged life cycle employment patterns between those with vocational and general education. To elaborate on the importance of cohort and period effects for averaged life cycle trajectories we replicate the most common research strategy from previous research and assess the robustness of the results when we introduce period and cohort measures. First, we model employment trajectories using both linear and quadratic polynomials without controlling for cohort and period effects (see in the Appendix Figures A2a for women, A2b for men). Second, we control explicitly measured macro-variables to capture period effects (Figure A2c for women, Figure A2d for men) and cohort dummies (Figure A2e for women, Figure A2f for men), and a combination of period effects and cohort dummies (Figure A2g for women, Figure A2h for men). The results remain fairly robust, regardless of which effect (period or cohort) is controlled. Thus, if we simply consider period and cohort effects as a form of bias, averaged life cycle trajectories are only marginally affected.

Using a completely flexible approach as described in Equation (1), we estimate non-parametric state probability models and present them as conditional profile and conditional effect plots. The conditional profile plot delivers a predicted unemployment probability curve for the vocationally versus the generally educated, plotted in Figures $2 \mathrm{a}$ and $2 \mathrm{c}$ for women and men, respectively. The conditional effect plots in Figures $2 b$ and $2 d$ show the employment probability differential of vocationally educated over generally educated women and men, respectively.

Figure $2 \mathrm{a}$ and Figure $2 \mathrm{~b}$ illustrate that the most common research strategy characterized by computing linear and quadratic polynomials leads to erroneous conclusions for women. As such functional forms are over-simplistic, they do not reflect the complexity of

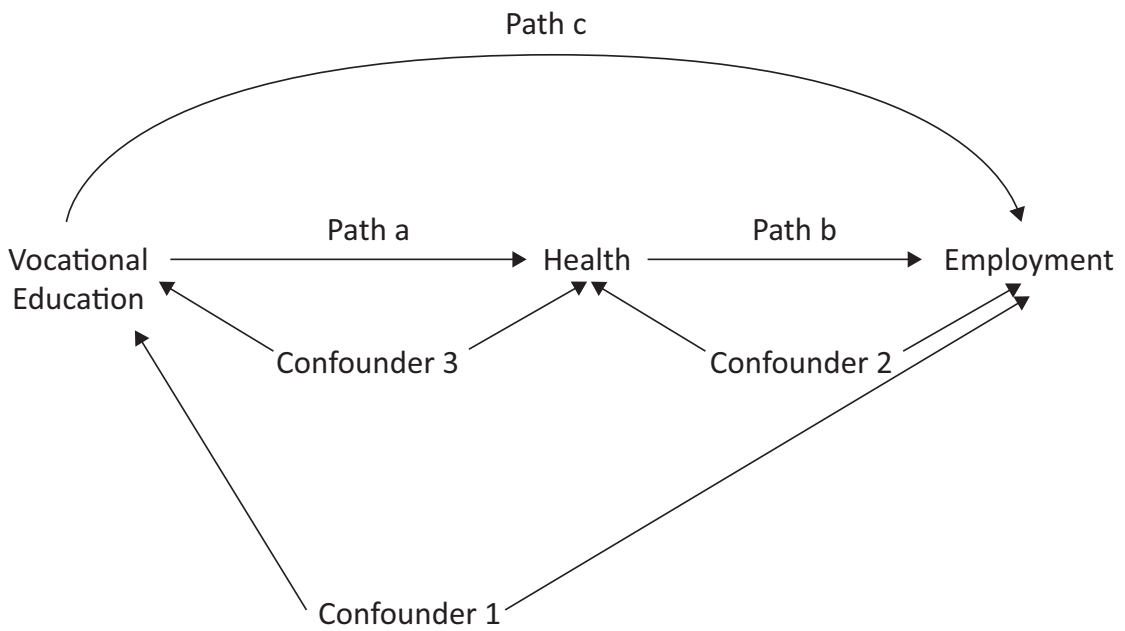

Figure 1. Paths from vocational education to employment and un-confounding assumptions. 
a) Profile plot (women)

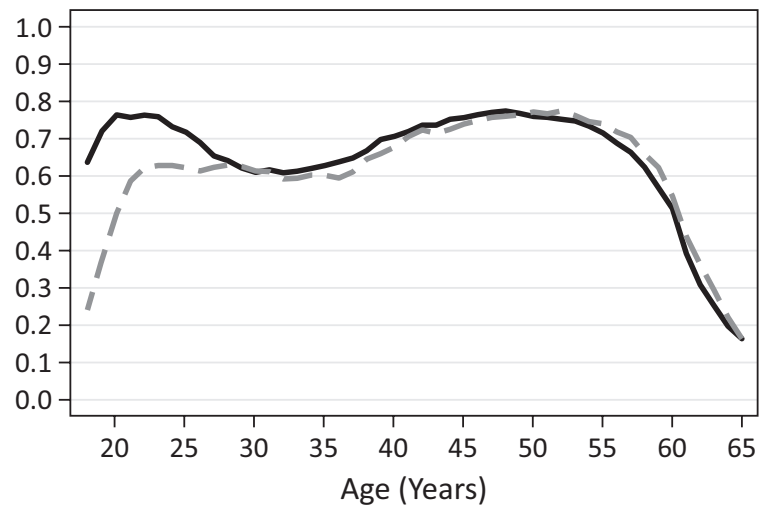

c) Profile plot (men)

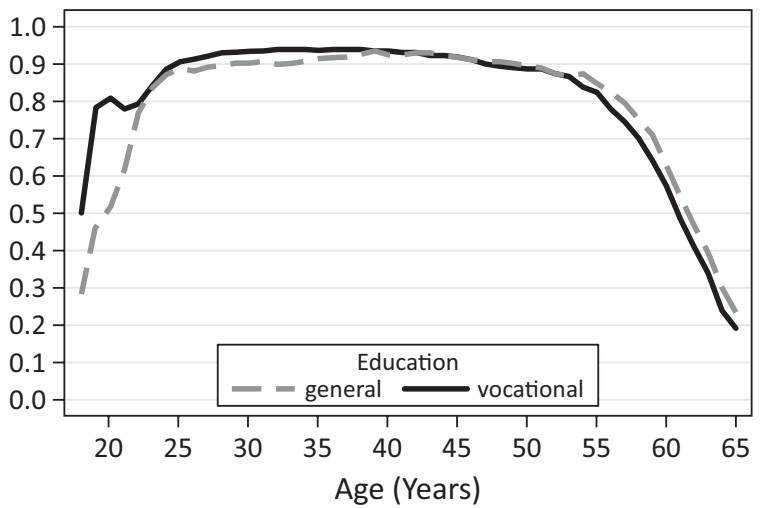

b) Effect plot (women)

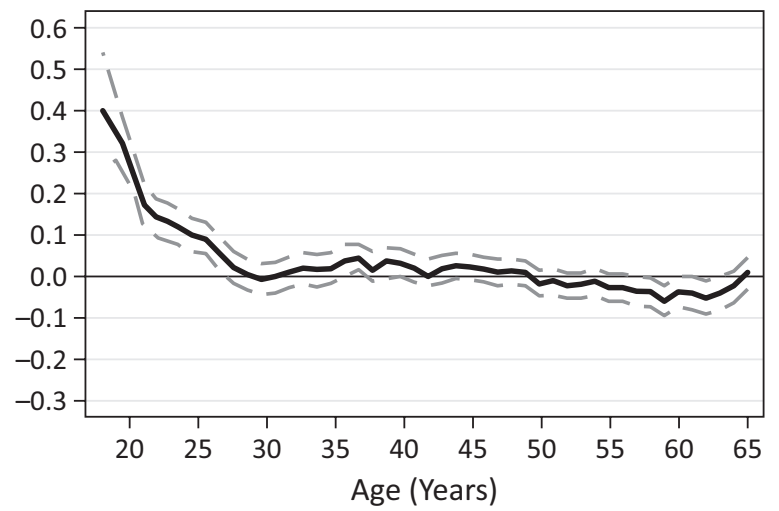

d) Effect plot (men)

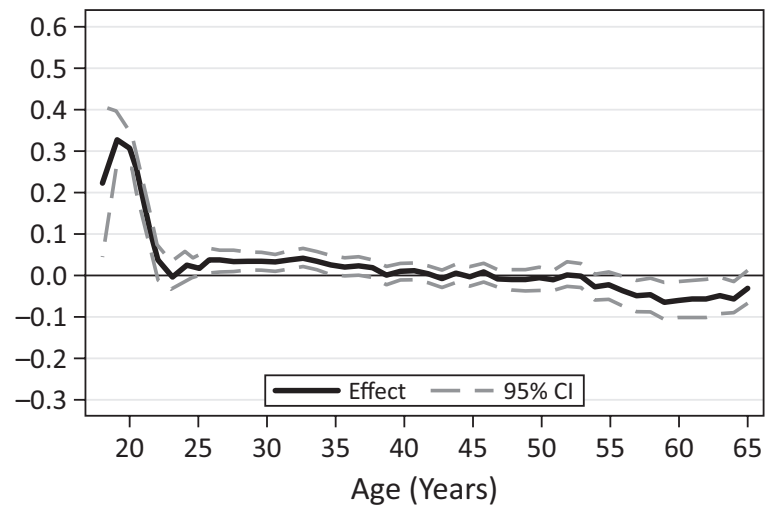

Figure 2. Employment opportunity over the life course: General versus vocational education by gender. Notes: Conditional profile plots (left) and conditional effect plots (right) estimated by gender-specific non-parametric state probability models of vocational and general education on employment probabilities. Control variables include period effects, cohort effects, German nationality, parental educational background, residence in West Germany, and educational level. N persons $=44,502 ; \mathrm{N}$ person-years $=332,537$. See Table A4 in the Appendix for detailed regression results. Data source: GSOEP (n.d.).

the female life course. Further analyses (see Figure 3) show that parental leave in particular leads to an age-employment trajectory with three turning points for women.

However, regarding qualitative conclusions, our results are very similar to previous research: Vocational education increases employment chances at the beginning of the working career, whereas general education leads to better employment chances at the end. This pattern is more pronounced for men than for women. Similar to the Netherlands (Forster \& Bol, 2018), we see large initial gains from vocational education in terms of employment prospects, which are not fully compensated later in the career by general education. Furthermore, Figure 2 shows that the turning point of the trade-off seems to lie at an older age than estimated by Hanushek et al. (2017); namely, around 55 (for men).

\subsection{Gender and Cohort Variations in Life Cycle Patterns}

We now proceed with a systematic assessment whether the life course trajectories outlined above vary by cohort.
Figure 4 shows employment patterns of women with vocational and general education by cohort: Employment rates increased considerably between cohort 1 (born between 1919 and 1945) and cohort 2 (born between 1946 and 1959). At the same ages (between 45 and 65) the employment rate is around 15 percentage points higher for the younger cohort for both the generally and the vocationally educated. Furthermore, the late-life reversal is only apparent for cohort 1 , but not for cohort 2 .

A remarkable pattern emerges when comparing the early life course between birth cohort 3 (born between 1960 and 69), cohort 4 (born between 1970 and 79), and cohort 5 (born between 1980 and 1998). Here, the age-specific employment pattern of the vocationally educated remains fairly stable across all three cohorts, whereas employment opportunities in the general education group decreased remarkably. While the latter had an employment advantage between 30 and 35 for cohort 3, we find no advantage for cohort 4, and a disadvantage for cohort 5 . Thus, for women, the early life course advantage of vocational education increased across cohorts. 
a) general education (women)

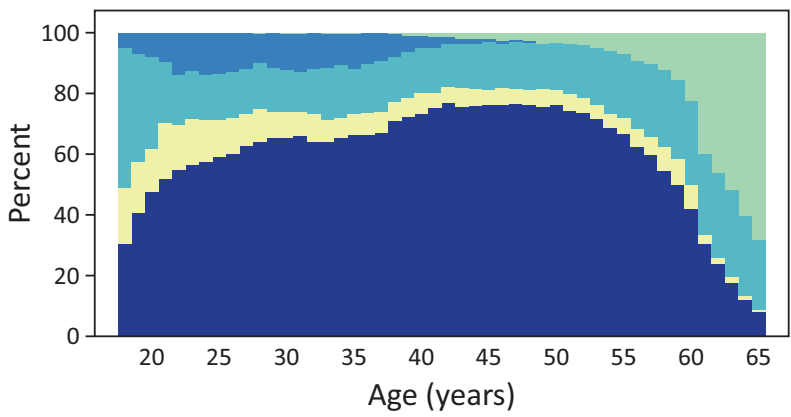

c) general education (men)

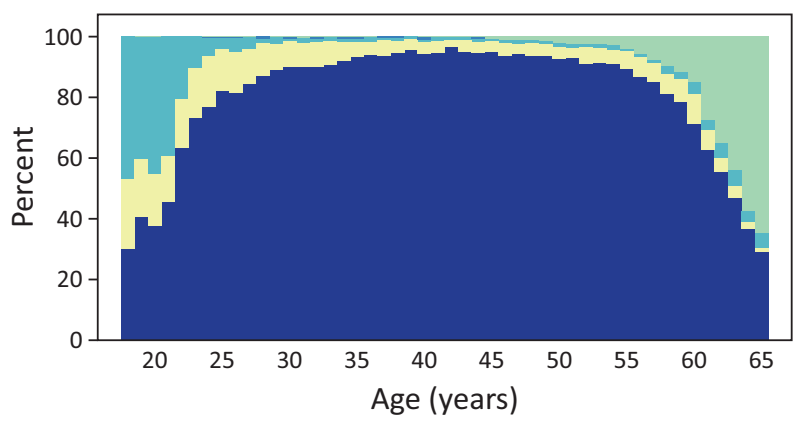

Working Unemployed b) vocational education (women)

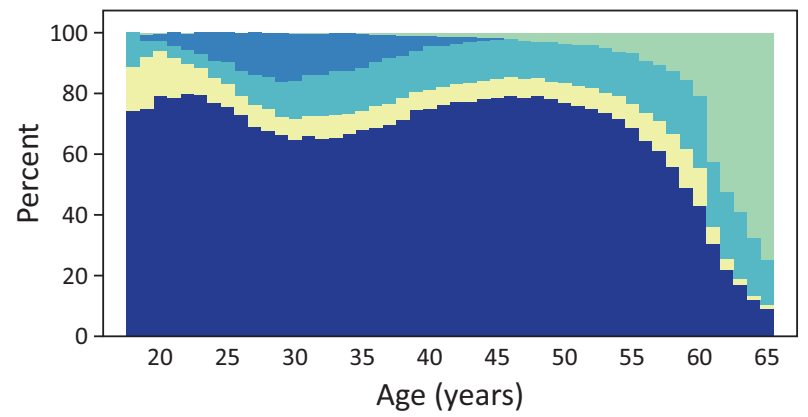

d) vocational education (men)

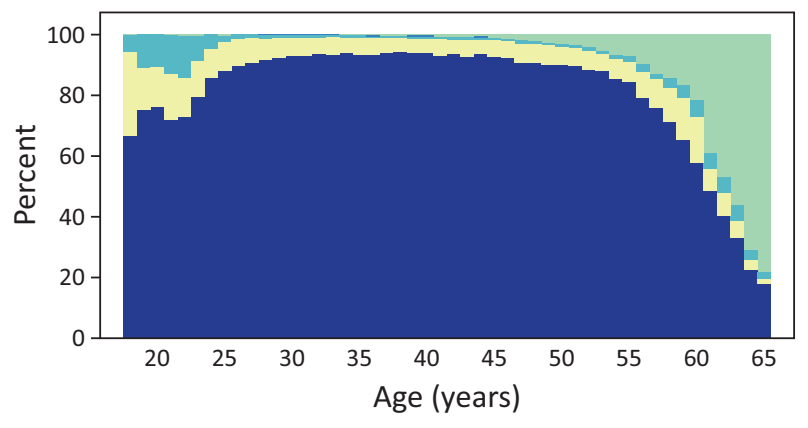

Non-Working

Parental Leave

Retired

Figure 3. Employment status by education type, age, and gender. Data source: GSOEP (n.d.).

While employment participation has risen for women across cohorts, employment rates of men remain relatively stable at a high level (Figure 5 ). In contrast to the findings for women, the late-life reversal for men is found for cohort 1 and cohort 2 . In accordance with the pattern of women, employment rates of the vocationally educated remained stable across cohort 3 , cohort 4, and cohort 5, while employment chances of the generally educated decreased remarkably between cohorts 4 and 5 .

These results raise the question as to why the employment opportunities of those with generally education decrease across cohorts. Educational expansion has resulted in an increasing share of young adults in education in later born cohorts. As individuals in education do not enter this analysis, the sample in this young age period becomes increasingly selective across cohorts. This increasing selectivity is more pronounced for general education. Further analyses revealed that the decreasing employment prospects of the generally educated between 20 and 25 across cohorts is driven by young adults who enter the labor market without tertiary education and without a vocational degree. This group has become increasingly negatively selected across cohorts.

However, as Figure 4j and Figure $5 \mathrm{j}$ show, there is also a significant advantage of vocational education between ages 30 and 35 . At this age, the majority of those with tertiary education have also finished their educational career. Comparing these results with the nonexistent advantage of vocational education in earlier born cohorts in this age range (Figures $4 h, 4 f, 5 h$ and $5 f$ ) suggests that the relative advantage of the vocationally educated in total (and not only of the not-tertiary educated) have increased across cohorts.

\subsection{Mediation Analyses: Health as a Potential Mechanism Explaining Differences at the End of Working Life}

In this section, we investigate how much of the late-life reversal of employment opportunity is due to a faster deterioration of health among those with vocational education (indirect effect), and how much of the total effect does not work through health (direct effect). We focus on men, because the reasoning of a faster health decline due to more physically demanding jobs for the vocationally educated applies especially to men. We begin with an assessment of the impact of vocational versus general education on health satisfaction (Equation 2, Figure 6). The results show that the two groups do not significantly differ in health satisfaction until 43 years of age. Thereafter, however, a significant health disadvantage appears for those with vocational education.

Having observed that this subgroup indeed shows a faster health decline, we now ask whether the decrease in health mediates a significant proportion of the lower employment probability of this group after midlife. To this end, we conducted $11 \mathrm{KHB}$ mediation analyses for each age and plotted the results in Figure 7. Here, health is measured not only by health satisfaction, but also by 
a) Cohort 1: 1919-1945

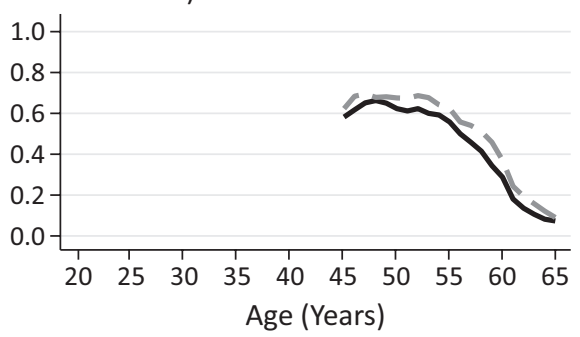

c) Cohort 2: 1946-1959

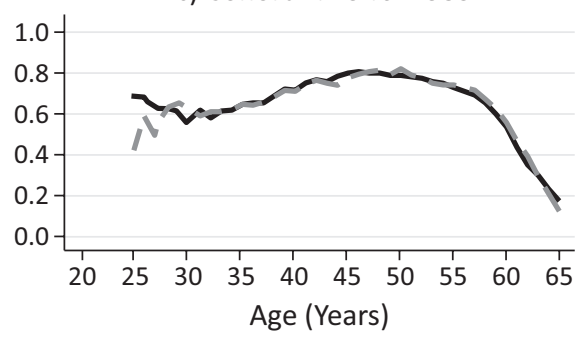

e) Cohort 3: 1960-1969

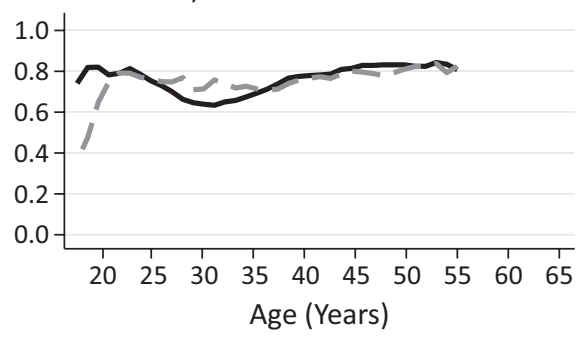

g) Cohort 4: 1970-1979

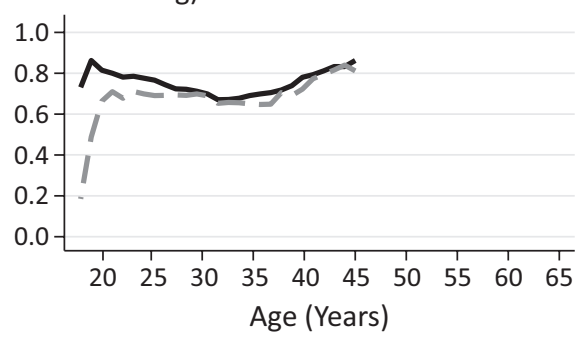

i) Cohort 5: 1980-1998
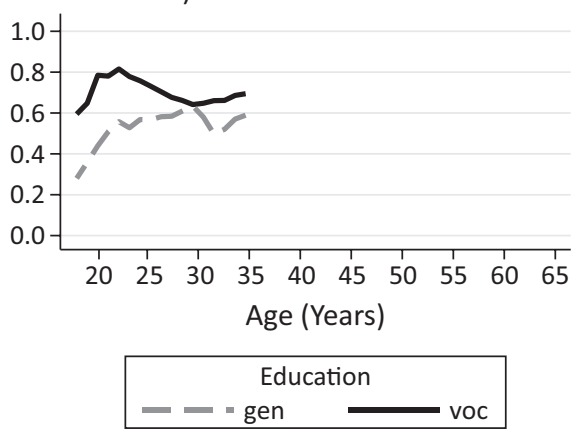

b) Cohort 1: 1919-1945

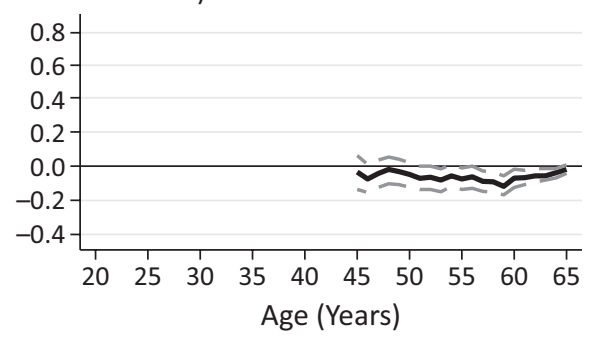

d) Cohort 2: 1946-1959

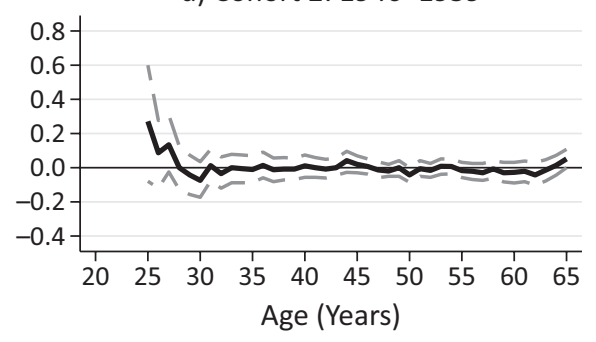

f) Cohort 3: 1960-1969

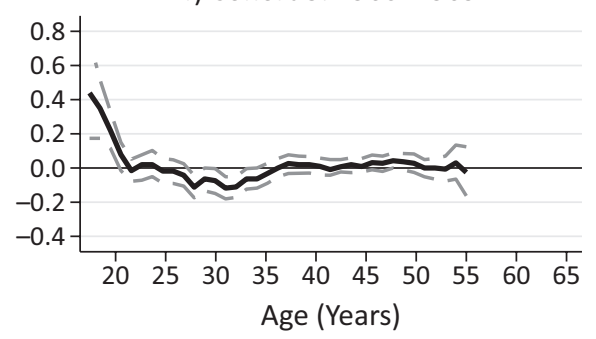

h) Cohort 4: 1970-1979

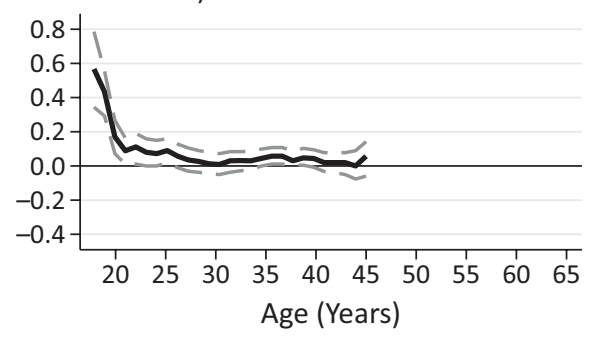

j) Cohort 5: 1980-1998

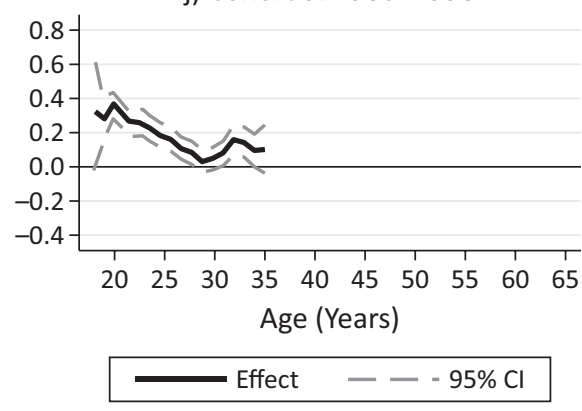

Figure 4. Cohort variation in employment opportunity over the life course: General versus vocational education (women). Notes: Conditional profile plots (left) and conditional effect plots (right) estimated by cohort-specific non-parametric state probability models of vocational and general education on employment probabilities of women. Control variables include period effects, German nationality, parental educational background, residence in West Germany, and educational level. $\mathrm{N}$ persons $($ cohort 1$)=3,365 ; \mathrm{N}$ person-years $($ cohort 1$)=29,210 ; \mathrm{N}$ persons (cohort 2$)=4,870 ; \mathrm{N}$ person-years $($ cohort 2) = 52,077; $N$ persons (cohort 3) = 5,752; N person-years (cohort 3) = 48,657; N persons (cohort 4) = 5,094; $N$ personyears (cohort 4$)=30,994 ; N$ persons (cohort 5) =4,135; $N$ person-years (cohort 5) $=13,870$. See Tables A5 and A6 in the Appendix for detailed regression results. Data source: GSOEP (n.d.). 
a) Cohort 1: 1919-1945

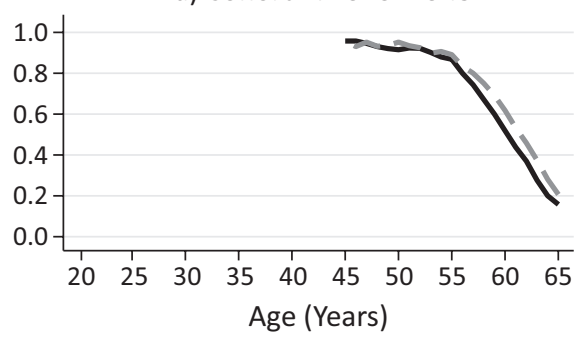

c) Cohort 2: 1946-1959

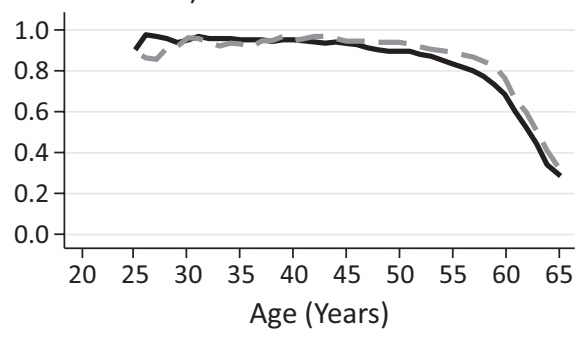

e) Cohort 3: 1960-1969

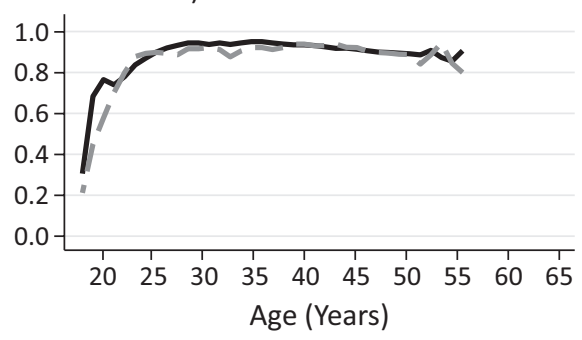

g) Cohort 4: 1970-1979

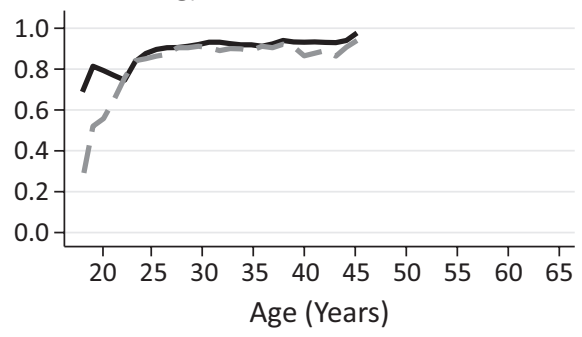

i) Cohort 5: 1980-1998
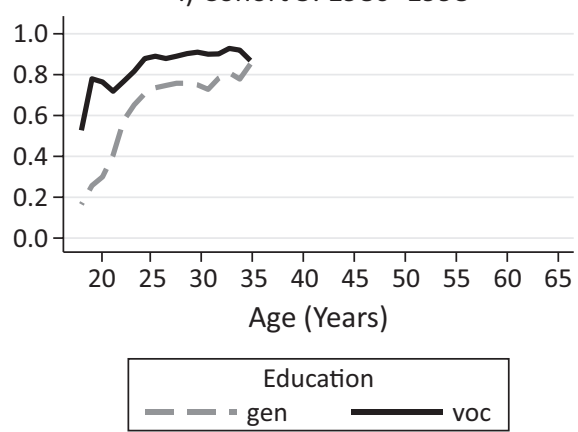

b) Cohort 1: 1919-1945

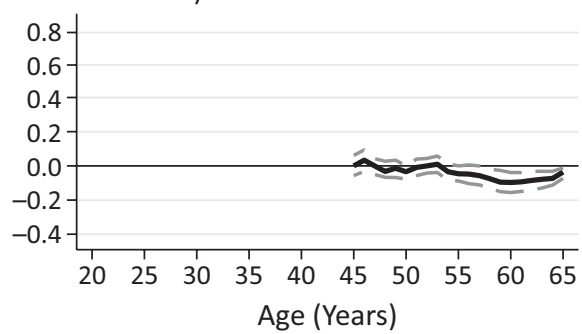

d) Cohort 2: 1946-1959

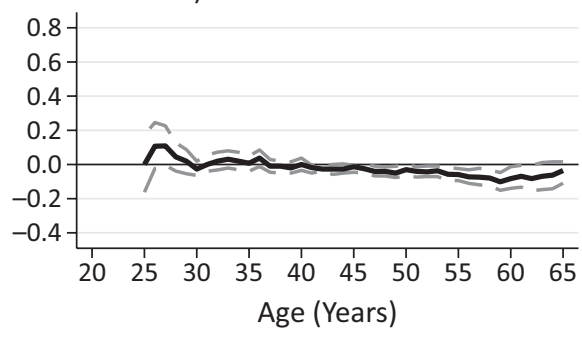

f) Cohort 3: 1960-1969

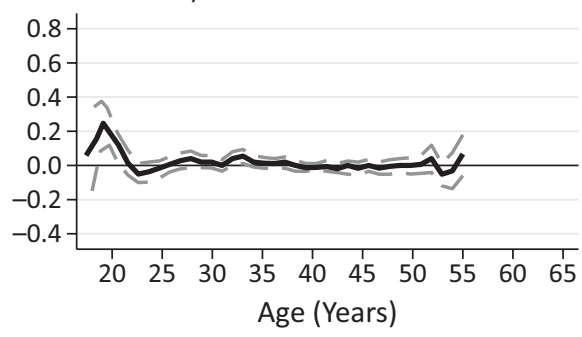

h) Cohort 4: 1970-1979

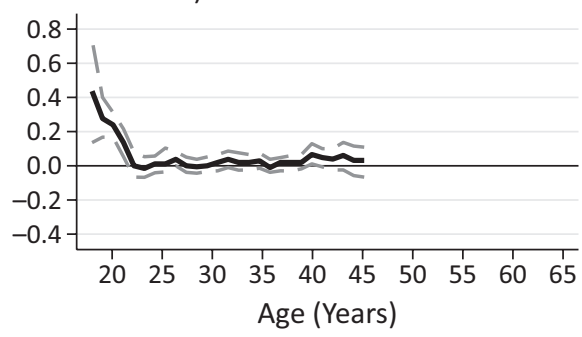

j) Cohort 5: 1980-1998

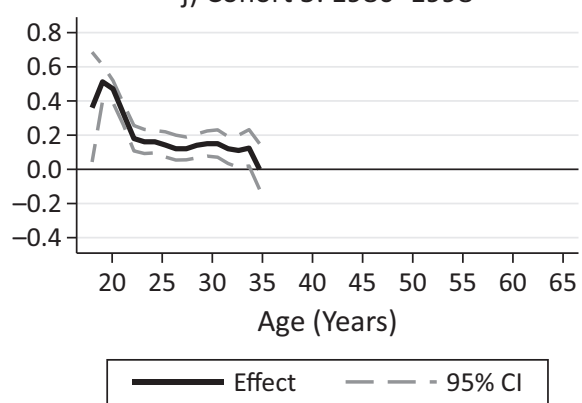

Figure 5. Cohort variation in employment opportunity over the life course: General versus vocational education (men). Notes: Conditional profile plots (left) and conditional effect plots (right) estimated by cohort-specific non-parametric state probability models of vocational and general education on employment probabilities of men. Control variables include period effects, German nationality, parental educational background, residence in West Germany, and educational level. $\mathrm{N}$ persons (cohort 1$)=3,232 ; \mathrm{N}$ person-years (cohort 1$)=28,299 ; \mathrm{N}$ persons (cohort 2$)=4,778$; $\mathrm{N}$ person-years (cohort 2) =49,022; $N$ persons (cohort 3) = 5,463; N person-years (cohort 3) =45,160; $N$ persons (cohort 4) $=4,205 ; \mathrm{N}$ personyears $($ cohort 4$)=24,377 ; N$ persons (cohort 5) =3,547; $N$ person-years (cohort 5) $=10,871$. See Tables A7 and A8 in the Appendix for detailed regression results. Data source: GSOEP (n.d.). 
a) Profile plot (men)

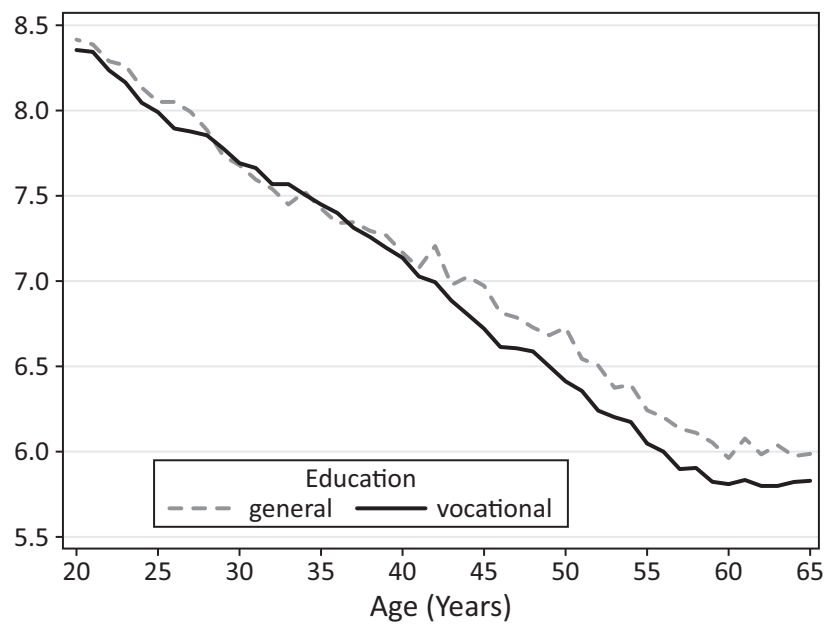

b) Effect plot (men)

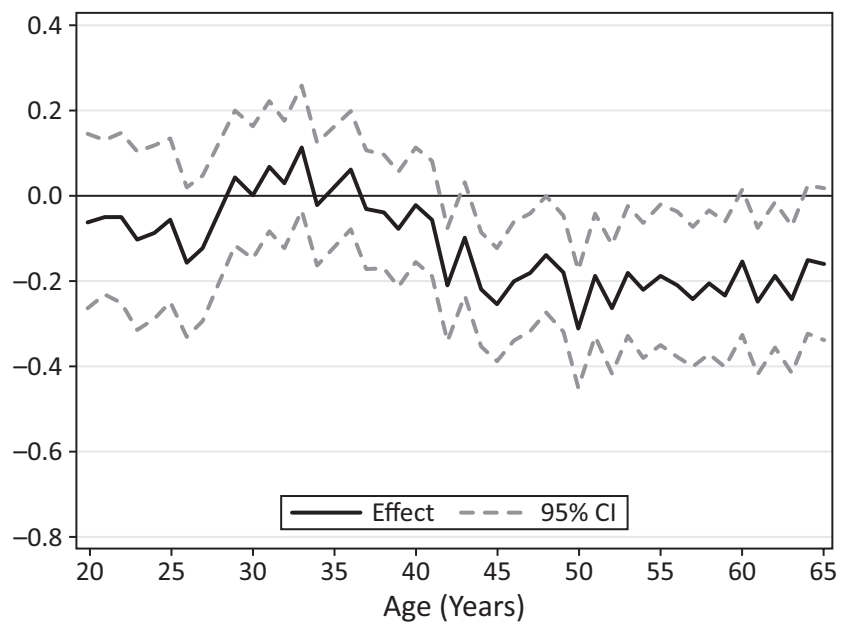

Figure 6. Health satisfaction over the life course: General versus vocational education for men. Note: Conditional profile plots (left) and conditional effect plots (right) estimated by non-parametric models of vocational and general training on health satisfaction. Control variables include period effects, cohort effects, German nationality, parental educational background, residence in West Germany, and educational level. N persons = 20,554; N person-years $=146,548$. See Table A9 in the Appendix for detailed regression results. Data source: GSOEP (n.d.).

disability status, nights spent in hospital per year, and the number of doctor visits. Figure 7 shows that a part of the total late-life disadvantage works through health. The significance of this indirect effect depends on the estimation approach: If we pool all age years (55-65) and control for age the overall indirect effect of health is significant. However, if we differentiate by each age as shown in Figure 7, the indirect effect is only significant at ages 57 and 65 (age 63 scratches significance: $p=0.053$ ). The corresponding mediated percentage reaches from $5 \%$ at 59 to $50 \%$ at 65 years of age. The relatively high mediated percentage at age 65 is driven by a small total effect, whereas the indirect effect at this age is comparable in size to that at other ages. In contrast to the indirect effect of vocational versus general education via health, the direct effect is significant at most ages (57-60 and 62-64). Furthermore, Figure 7 shows that the majority of the total effect is a direct effect, not mediated through health.

\section{Sensitivity Analyses: The Role of Double Qualifications}

One of the most problematic issues when assessing returns to vocational education and general education is how to handle cases with double qualifications. In our sample, $6.7 \%$ of respondents attained both a vocational and a general degree over the life course. Most of these individuals did not attain both degrees at the same time, but in a temporal order: While some first attain a general and later a vocational degree, most attain first the vocational and later the general degree (sometimes as part of company-internal further education). We argue that in a typical life course, the vocational degree precedes the general. Therefore, we argue that in such situations, the attainment of the second general degree is endoge- nous to the first vocational degree. Hence, we have valued cases with double qualifications as having attained vocational education.

There are at least three further ways to deal with double qualifications that combine vocational and general education: (1) model such cases explicitly and compare employment trajectories with both the vocationally and the generally educated, (2) define them as generally educated, or simply (3) drop them. We consider the first approach to be the gold standard for comparing and explaining late-life employment patterns. However, it is not possible to model double qualifications explicitly when comparing and explaining early life employment patterns, as individuals start out with one qualification and then either apply for a position or begin a new education or training programme. In our sample, the earliest age at which trajectories can be compared is 26 due to low numbers of individuals with double qualifications before that age ( $\mathrm{N}=72$ for 25 years of age). Thus, one possible estimation strategy would be to drop all information below age 26 and compare the three groups (vocational, general, and double). However, this modelling strategy only allows for a comparison of those with double qualifications from the time point when they have both qualifications. We therefore miss the employment trajectory at young ages after the obtainment of their first education.

Option 2 also has clear drawbacks: If individuals enjoy high employment probabilities at young ages due to their vocational education and then later on obtain a general education degree, the smooth labour market transition that was due to vocational education is erroneously assessed to be due to general education. Option 3 is also problematic. When individuals obtain a vocational or general degree first and afterwards a second degree; then it is highly likely that both the first degree and the 
a) Total, direct, indirect effect

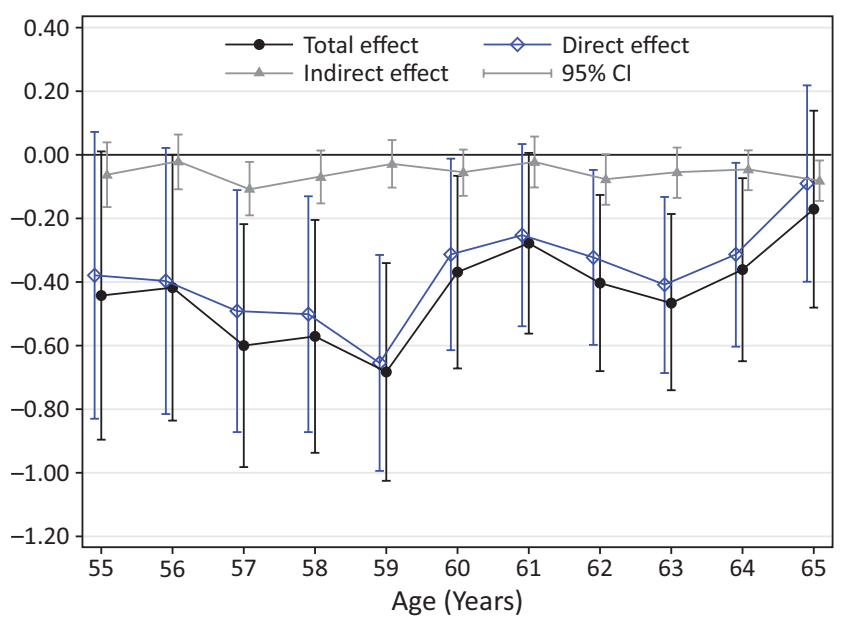

b) Percentage mediated

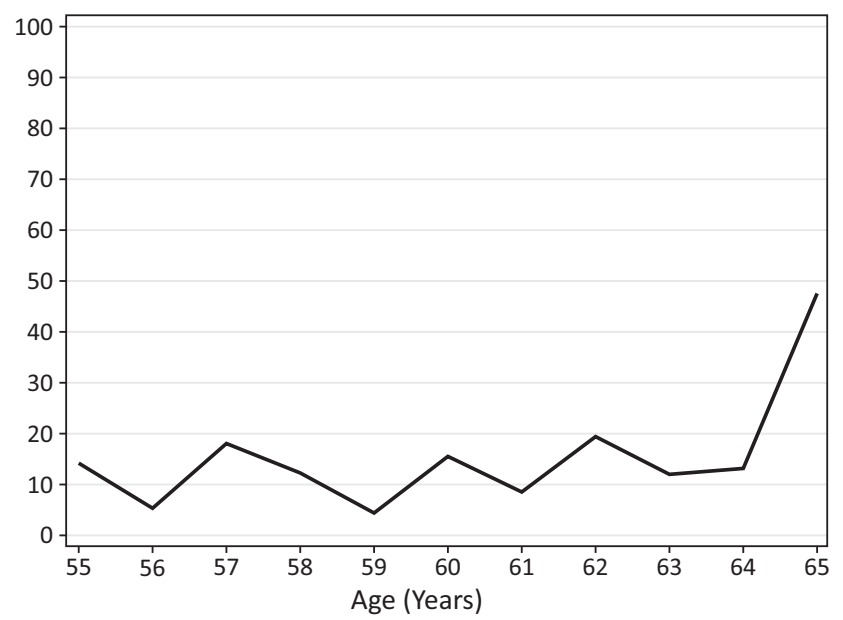

Figure 7. KHB mediation analysis of total, direct, and indirect effects of general versus vocational education on employment probability (not) via health for men. Notes: Total and direct effect of general versus vocational education on age-specific employment probabilities. Indirect effects via health are significant at age 57 and 65 . Figure 7 a reports log odds. Mediator variables include nights spent in hospital, doctor visits, disability status, and health satisfaction. Control variables include period effects, cohort effects, German nationality, parental educational background, residence in West Germany, and educational level. $\mathrm{N}$ persons $=6,026 ; \mathrm{N}$ person-years $=32,469$. Detailed regression results available upon request. Data source: GSOEP (n.d.).

employability situation after the first degree influence the decision to obtain the second degree. Thus, if we drop those with two degrees, we implicitly condition on a collider and the results may be biased due to endogenous selection bias (Elwert \& Winship, 2014).

In this robustness section, we present selected results in order to assess the degree of difference between the above sketched options. Figure A3 presents the employment curves for those with double qualifications as compared to those with only vocational and only general degrees. For women, the results show that those with double qualifications have the highest employment probabilities of all three groups until age 52 . Between the ages of 53 and 62, employment probabilities do not differ from those with general education only. In later life, employment changes are more similar to those of individuals with vocational education.

For the assessment of the late-life reversal, this pattern has the following implications for women: If those with double qualifications are categorized as having a general education, we estimate an earlier and stronger late-life reversal until the age of 52 and as well a higher late-life reversal from age 53 until 62. After 63, we estimate the same gap with larger confidence intervals. If we exclude this group, the magnitude of the late life-reversal effect until age 52 and again between ages 53 and 62 becomes more pronounced and stays roughly the same after 63 years of age (due to lower number of observations with larger confidence intervals).

For men, the employment pattern of those with double qualifications does not differ substantially from those with vocational education. For the assessment of the late-life reversal, this pattern has the following implica- tions for men: option 2 results in a lower estimation of the late-life reversal effect. If excluded (option 3 ), the magnitude of the late-life reversal is roughly the same as estimated in Section 5.1 (as the employability pattern does not differ from those of vocationally educated), while confidence intervals increase due to the lower number of cases.

In a second step, we investigate how these differences in measurement affect cohort variations in life course patterns. Due to very small sample sizes of individuals with double qualifications by cohort and age, we are not able to model this group explicitly. Therefore, they were excluded from the analyses. For women, Figure A4 shows that the late-life reversal effect in the earliest born cohort (1919-1945) is roughly the same as in Figure 4, with larger confidence intervals. Results for the other cohorts do not differ between Figure 4 and Figure A4, and are thus not substantially affected by different operationalisations. For men, effect sizes for the oldest cohort (Figure A5) are quite similar to those in Figure 5, aside from larger confidence intervals in the restricted sample. However, for cohort 2, effect sizes differ substantially: no late-life reversal effect is found for the reduced sample. Comparing employment patterns of Figure 5 and Figure A5, the remaining cohort differences are shown to be fully robust when estimated with the restricted sample.

Figure A6 shows that health trajectories of men with double qualifications follow those with general education until 58 years of age. Thereafter, health satisfaction declines faster for those with double qualifications. Thus, the results on health satisfaction would be more pronounced if double qualifications were categorized as gen- 
eral education. Furthermore, they would also be more pronounced if excluded.

Finally, Figure A7 shows the somewhat chaotic results for the mediation analysis with the restricted sample. The total effect is only significant for 59 and 64 years of age, losing significance for the other ages. Direct effects are only significant for 59 years of age, whereas indirect effects are not significant for any age. Figure A7b shows the percentage mediated, which is only a meaningful measure when total direct and indirect effects point in the same direction (VanderWeele, 2015). Therefore, we only show this measure after 57 years of age: The percentage mediated circulates around the same magnitude for the restricted sample.

\section{Conclusion and Discussion}

This study set out to make three important contributions to the lively scientific discussion about returns to vocational and general education over the life course. First, this study dedicates itself to a systematic assessment of cohort variations in life cycle employment patterns between those with general and vocational education. Second, we deliver a systematic assessment of how health in both groups evolves over the life course. Third, we scrutinize health differences as an intervening, mediating mechanism that explains the late-life employment disadvantage of the vocationally educated.

Regarding the importance of cohort effects, our literature review indicated that while several previous studies investigated international variations of the link between general and vocational education and employment patterns over the life course, studies assessing cohort variations are sparse. Therefore, we used longrunning multi-cohort panel data to assess cohort variations in life cycle patterns. We propose a theory-guided restriction to control for explicitly measured macrovariables that capture period effects in order to avoid the issue of linear dependency that arises when scholars aim to control for period and cohort effects to estimate age effects. This modelling strategy allows us to control for cohort effects via dummy variables, resting on the assumption that after including explicitly measured period variables, no period trends that are systematically related to age-specific employment differences between the vocationally and the generally educated remain.

While cohort differences do not systematically distort averaged life cycle patterns, averaging age-employment patterns across cohorts masks cohort-specific differences in life cycle patterns as employment patterns vary heavily between cohorts. In particular, the advantage of vocational education at younger ages becomes more pronounced across cohorts. Thus, a modelling strategy that does not explicitly consider such cohort differences misses the boundary conditions that weaken or strengthen the link between vocational versus general education and employability. In contrast, our differentiated research finding suggests that vocational education as a buffer against the risk of employment insecurity and job shopping at the beginning of the professional career has become increasingly important across cohorts.

Regarding health effects, this study illustrates that men with vocational education indeed show a steeper health decline than those with general education. Whereas no significant health differences exist at younger ages, the vocationally educated suffer from lower health satisfaction after midlife. This empirical pattern constitutes an important research finding that supports broadening the scope of research when assessing returns to general versus vocational education. While there is a fast-emerging literature assessing nonmonetary returns to education, the literature on vocational versus general education has almost exclusively focused on pecuniary returns.

When it comes to the mediating role of such health differences for the explanation of the lower employability of those with vocational education at older ages, we found that a part of the total effect works through health. We consider this approach as a first step in the direction of explicitly specifying intervening mediating mechanisms and testing such mechanisms using methods of mediation analysis.

Of course, this study has its shortcomings. A causal interpretation of the association between vocational and general education and employment (or health) requires the assumption that there are no unobserved variables between these explanatory variables and the outcomes. However, this assumption is quite unrealistic. As we have outlined in the method section, the identification of direct and indirect effects requires even stronger assumptions than the identification of a total effect. We believe that our efforts to control for period and cohort effects, which are usually unmeasured confounders in previous research, is a step in the right direction. However, there are likely to be more unmeasured confounders at play that endanger a causal explanation. Therefore, as we do not have a causal design, our results are perhaps best regarded as a detailed multivariable description that helps to uncover a broad picture of research explananda.

Furthermore, our finding that the employment advantage of the vocationally educated has become more pronounced across cohorts is based on a comparison of the latest born cohort with the two older cohorts for which we observe career entry. The youngest cohort is particularly selective as many young individuals are still in education. Therefore, future research should assess whether the pattern of increasing employment advantage of vocational education at the beginning of the professional career is still valid once this youngest cohort has become older and entered the labour market entirely. Furthermore, future research should clarify if the pattern of increasing returns of vocational education at the beginning of the professional career holds for future cohorts.

The definition of vocational and general education is another fundamental point. We followed the convention 
of previous studies in this field by distinguishing the two groups only with regard to the formal programme type. Furthermore, we presented detailed sensitivity checks that show, in detail, how the decision to handle cases with double qualifications affects results. Similar to other studies, we neglected the fact that the skill content of vocational education and training as well as of higher education programmes strongly differs with regard to its specificity and applicability in different segments of the labour market. In reality, there are highly specific programmes in tertiary education (e.g., medical specialists) and highly general programmes in vocational education and training (e.g., salespersons). This neglect was mainly due to data restrictions: neither PIAAC nor GSOEP data contain information on course content or precise field of study, which would be necessary to identify the degree of vocational programme specificity. Future research in this direction could be conducted with NEPS-SC6 data.

Aside from these limitations, this study has important strengths. It is the first of its kind to show significant cohort variations in life cycle patterns between vocationally and generally educated women and men. Moreover, it provides evidence of a faster health decline among those with a vocational background and shows that some percentage of the total effect of vocational versus general education may work through a faster health deterioration.

\section{Acknowledgments}

We thank the editors and two anonymous reviewers for valuable comments on an earlier version of the manuscript and Madison Garrett and Dennis Wolfram for proofreading.

\section{Conflict of Interests}

The authors declare no conflict of interests.

\section{References}

Bell, A., \& Jones, K. (2014a). Don't birth cohorts matter? A commentary and simulation exercise on Reither, Hauser, and Yang's (2009) age-period-cohort study of obesity. Social Science \& Medicine, 101, 176-180. https://doi.org/10.1016/j.socscimed.2013.09.004

Bell, A., \& Jones, K. (2014b). Another 'futile quest'? A simulation study of Yang and Land's hierarchical ageperiod-cohort model. Demographic Research, 30(11), 333-360. https://doi.org/10.4054/DemRes.2014.30. 11

Bell, A., \& Jones, K. (2015). Should age-period-cohort analysts accept innovation without scrutiny? A response to Reither, Masters, Yang, Powers, Zheng and Land. Social Science \& Medicine, 128, 331-333. https://doi.org/10.1016/j.socscimed.2015.01.040

Brunello, G., \& Rocco, L. (2017). The labor market effects of academic and vocational education over the life cycle: Evidence based on a British cohort. Journal of Human Capital, 11(1), 106-166. https://doi.org/ 10.1086/690234

Brüderl, J., Kratz, F., \& Bauer, G. (2018). Life course research with panel data: An analysis of the reproduction of social inequality. Advances in Life Course Research. Advanced online publication. https://doi.org/ 10.1016/j.alcr.2018.09.003

Chauvel, L., \& Schröder, M. (2015). The impact of cohort membership on disposable incomes in West Germany, France, and the United States. European Sociological Review, 31(3), 298-311. https://doi.org/10. 1093/esr/jcu091

Cörvers, F., Heijke, H., Kriechel, B., \& Pfeifer, H. (2011). High and steady or low and rising? Lifecycle earnings patterns in vocational and general education (Discussion Paper ROA-RM-2011/7). Retrieved from https://papers.ssrn.com/sol3/papers. cfm?abstract_id=2569055

Elwert, F., \& Winship, C. (2014). Endogenous selection bias: The problem of conditioning on a collider variable. Annual Review of Sociology, 40, 31-53. https:// doi.org/10.1146/annurev-soc-071913-043455

Fienberg, S. E. (2013). Cohort analysis' unholy quest: A discussion. Demography, 50(6), 1981-1984. https:// doi.org/10.1007/s13524-013-0251-z

Forster, A. G., \& Bol, T. (2018). Vocational education and employment over the life course using a new measure of occupational specificity. Social Science Research, 70, 176-197. https://doi.org/10.1016/j. ssresearch.2017.11.004

Forster, A. G., Bol, R., \& van de Werfhorst, H. (2016). Vocational education and employment over the life cycle. Sociological Science, 3, 473-194. https://doi.org/ 10.15195/v3.a21

German Socio-Economic Panel (n.d.). Data for years 1984-2015, version 32. SOEP. Retrieved from https://www.diw.de/de/diw_01.c.548849.de/ soep_v32.html

Glenn, N. D. (2005). Cohort analysis. Thousand Oaks, CA: Sage Publications.

Goebel, J., Grabka, M. M., Liebig, S., Kroh, M., Richter, D., Schröder, C., \& Schupp, J. (2019). The German socio-economic panel (SOEP). Jahrbücher für Nationalökonomie und Statistik, 239(2), 345-360. https:// doi.org/10.1515/jbnst-2018-0022

Golsteyn, B. H., \& Stenberg, A. (2017). Earnings over the life course: General versus vocational education. Journal of Human Capital, 11(2), 167-212. https:// doi.org/10.1086/691798

Haisken-DeNew, J. P., \& Frick, J. R. (2005). Desktop companion to the German socio-economic panel study (GSOEP). Berlin: German Institute for Economic Research.

Hampf, F., \& Woessmann, L. (2017). Vocational vs. general education and employment over the life-cycle: New evidence from PIAAC. CESifo Economic Studies, 63(3), 255-269. https://doi.org/10.1093/cesifo/ 
ifx012

Hanushek, E., Schwerdt, G., Woessmann, L., \& Zhang, L. (2017). General education, vocational education, and labour-market outcomes over the life-cycle. Journal of Human Resources, 52(1), 48-87. https://doi.org/ 10.3368/jhr.52.1.0415-7074R

Heckman, J., \& Robb, R. (1985). Using longitudinal data to estimate age, period and cohort effects in earnings equations. In W. M. Manson \& S. E. Fienberg (Eds.), Cohort analysis in social research: Beyond the Identification Problem (pp. 137-150). New York, NY: Springer. https://doi.org/10.1007/978-1-46138536-3_5

Karlson, K. B., \& Holm, A. (2011). Decomposing primary and secondary effects: A new decomposition method. Research in Social Stratification and Mobility, 29(2), 221-237. https://doi.org/10.1016/j.rssm. 2010.12.005

Karlson, K. B., Holm, A., \& Breen, R. (2012). Comparing regression coefficients between same-sample nested models using logit and probit: A new method. Sociological Methodology, 42(1), 286-313. https://doi. org/10.1177\%2F0081175012444861

Kohler, U., Karlson, K. B., \& Holm, A. (2011). Comparing coefficients of nested nonlinear probability models. The Stata Journal, 11(3), 420-438. https://doi.org/ $10.1177 / 1536867 \times 1101100306$

Korber, M., \& Oesch, D. (2019). Vocational versus general education: Employment and earnings over the life course in Switzerland. Advances in Life Course Research, 40, 1-13. https://doi.org/10.1016/j.alcr. 2019.03.003

Kratz, F., \& Brüderl, J. (2017). Well-being over the life course: Analytical strategies, methodological fallacies and evidence from Germany. München: Institut für Soziologie. Ludwig-Maximilians-Universität (LMU).

Lavrijsen, J., \& Nicaise, I. (2017). Returns on vocational education over the life cycle: Between immediate labour market preparation and lifelong employability. International Review of Education, 63(2), 257-280. https://doi.org/10.1007/s11159-017-9630-9

Leopold, L., \& Leopold, T. (2018). Education and health across lives and cohorts: A study of cumulative (dis)advantage and its rising importance in Germany. Journal of Health and Social Behavior, 59(1), 94-112. https://doi.org/10.1177\%2F0022146517751206

Linden, A., \& Karlson, K. B. (2013). Using mediation analysis to identify causal mechanisms in disease management interventions. Health Services and Outcomes Research Methodology, 13(2/4), 86-108. https://doi. org/10.1007/s10742-013-0106-5
Luo, L. (2013). Assessing validity and application scope of the intrinsic estimator approach to the age-periodcohort problem. Demography, 50(6), 1945-1967. https://doi.org/10.1007/s13524-013-0243-z

Luo, L., Hodges, J., Winship, C., \& Powers, D. (2016). The sensitivity of the intrinsic estimator to coding schemes: Comment on Yang, Schulhofer-Wohl, Fu, and Land. American Journal of Sociology, 122(3), 930-961. https://doi.org/10.1086/689830

Mannheim, K. (1928). Das Problem der Generationen [The problem of generations]. Kölner Vierteljahrshefte für Soziologie, 7, 157-185, 309-330.

Manzoni, A., Härkönen, J., \& Mayer, K. U. (2014). Moving on? A growth-curve analysis of occupational attainment and career progression patterns in West Germany. Social Forces, 92(4), 1285-1312. https:// doi.org/10.1093/sf/sou002

Pelzer, B., te Grotenhuis, M., Eisinga, R., \& SchmidtCatran, A. W. (2015). The non-uniqueness property of the intrinsic estimator in APC models. Demography, 52(1), 315-327. https://doi.org/10.1007/ s13524-014-0360-3

Rodgers, W. L. (1982). Estimable functions of age, period, and cohort effects. American Sociological Review, 47(6), 774-787. https://doi.org/10.2307/2095213

Ryder, N. B. (1965). The cohort as a concept in the study of social change. In W. M. Mason \& S. E. Fienberg (Eds.), Cohort analysis in social research. Beyond the identification problem (pp. 9-44). New York, NY: Springer. https://doi.org/10.1007/978-14613-8536-3_2

Shavit, Y., \& Müller, W. (2000). Vocational secondary education. European Societies, 2(1), 29-50. https://doi. org/10.1080/146166900360710

Smith, H. L., Mason, W. M., \& Fienberg, S. E. (1982). Estimable functions of age, period, and cohort effects: More chimeras of the age-period-cohort accounting framework. Comment on Rodgers. American Sociological Review, 47(6), 787-793. https://doi.org/10. 2307/2095214

Sobel, M. E. (1982). Asymptotic confidence intervals for indirect effects in structural equation models. Sociological Methodology, 13, 290-312. https://doi.org/ $10.2307 / 270723$

VanderWeele, T. (2015). Explanation in causal inference: Methods for mediation and interaction. Oxford: Oxford University Press.

Verhaest, D., Lavrijsen, J., van Trier, W., Nicaise, I., \& Omey, E. (2018). General education, vocational education and skill mismatches: Short-run versus longrun effects. Oxford Economic Papers, 70(4), 974-993. https://doi.org/10.1093/oep/gpy026 


\section{About the Authors}

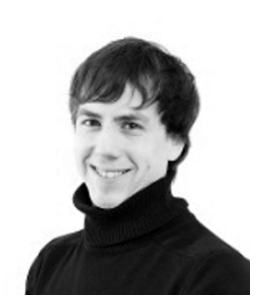

Fabian Kratz (Dr) is a Post-Doc in the Sociology Department at the University of Munich (LMU). He holds a Diploma in Sociology from University of Munich (LMU) and a doctorate in economics and social science from Friedrich-Alexander University Erlangen-Nürnberg (FAU). His research interests include transmission of inequality, migration, spatial research, and methodological issues.

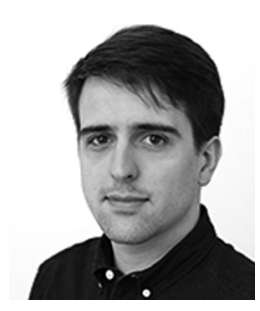

Alexander Patzina is a Researcher at the Institute for Employment Research (Germany) and a PhD candidate at the Friedrich-Alexander University Erlangen-Nürnberg (FAU). His research focuses on monetary and non-monetary returns to education over the life course and school-to-work transitions.

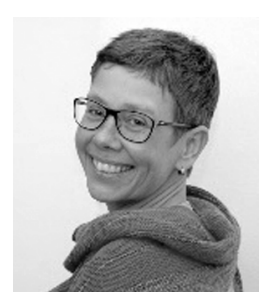

Corinna Kleinert (Dr) is Department Head at the Leibniz Institute for Educational Trajectories (LIfBi) and Professor of Sociology with focus on Longitudinal Education Research at the University of Bamberg. In her research, she is working on issues related to education and employment, social stratification, and gender inequality. She has also been involved in the development of large-scale surveys, among them the NEPS, the IAB study ALWA, and the DJI Youth Survey.

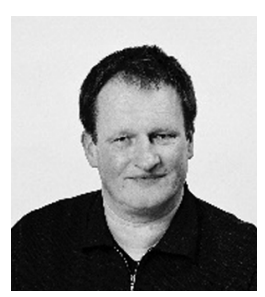

Hans Dietrich (Dr) is a Senior Researcher at the Institute for Employment Research (Germany). Research interests include education and the labour market of young people during the school-towork transition and the life course. 


\section{Appendix}

1. Tables

1.1. Data Description

Table A1. Distribution of model variables in sample 1 and sample 2. Data source: GSOEP (n.d.).

\begin{tabular}{|c|c|c|c|c|}
\hline & \multicolumn{2}{|c|}{ Sample 1} & \multicolumn{2}{|c|}{ Sample 2} \\
\hline & Mean & Std. Dev. & Mean & Std. Dev. \\
\hline Employed & 0.731 & & 0.733 & \\
\hline Vocational Education & 0.738 & & 0.740 & \\
\hline \multicolumn{5}{|l|}{ Level of Education } \\
\hline Lower \& Medium Secondary & 0.128 & & 0.125 & \\
\hline Higher Secondary & 0.533 & & 0.531 & \\
\hline Post-Secondary \& Tertiary I & 0.195 & & 0.199 & \\
\hline Tertiary II & 0.144 & & 0.145 & \\
\hline Health Satisfaction & - & & 6.830 & 2.144 \\
\hline Disability & - & & 0.084 & \\
\hline \multicolumn{5}{|l|}{ Hospital nights in "last" year } \\
\hline None & - & & 0.891 & \\
\hline 1 to 10 & - & & 0.074 & \\
\hline More than 10 & - & & 0.034 & \\
\hline \multicolumn{5}{|l|}{ Doctor visits in "last" year } \\
\hline None & - & & 0.328 & \\
\hline 1 to 10 & - & & 0.355 & \\
\hline More than 10 & - & & 0.316 & \\
\hline Sex: Female & 0.526 & & 0.527 & \\
\hline German Nationality & 0.966 & & 0.968 & \\
\hline Respondent lives in West Germany & 0.752 & & 0.756 & \\
\hline At least one parent with university education & 0.131 & & 0.132 & \\
\hline Unemployment Rate (in \%) & 9.558 & 1.824 & 9.637 & 1.828 \\
\hline GDP Growth Rate (in \%) & 1.724 & 2.027 & 1.699 & 1.959 \\
\hline Growth Rate of Real Disposable Income (in \%) & 3.182 & 2.275 & 3.103 & 2.248 \\
\hline Year After the Financial Crisis (2009) & 0.033 & & 0.036 & \\
\hline Year Before Cuttings in Unemployment Benefits (2004) & 0.038 & & 0.040 & \\
\hline Age & 43.154 & 12.118 & 43.314 & 12.047 \\
\hline \multicolumn{5}{|l|}{ Cohorts } \\
\hline 1919-1945 & 0.173 & & 0.165 & \\
\hline 1946-1959 & 0.304 & & 0.304 & \\
\hline 1960-1969 & 0.282 & & 0.285 & \\
\hline 1970-1979 & 0.167 & & 0.172 & \\
\hline 1980-1998 & 0.074 & & 0.074 & \\
\hline \multicolumn{5}{|l|}{ Sample-Year } \\
\hline 1984 & 0.017 & & 0.018 & \\
\hline 1985 & 0.016 & & 0.018 & \\
\hline 1986 & 0.017 & & 0.018 & \\
\hline 1987 & 0.017 & & 0.018 & \\
\hline 1988 & 0.016 & & 0.017 & \\
\hline 1989 & 0.016 & & 0.017 & \\
\hline 1990 & 0.024 & & - & \\
\hline 1991 & 0.024 & & 0.025 & \\
\hline 1992 & 0.024 & & 0.025 & \\
\hline 1993 & 0.023 & & - & \\
\hline 1994 & 0.023 & & 0.025 & \\
\hline 1995 & 0.023 & & 0.024 & \\
\hline 1996 & 0.023 & & 0.024 & \\
\hline 1997 & 0.022 & & 0.024 & \\
\hline
\end{tabular}




\section{COGITATIO}

Table A1. (Cont.) Distribution of model variables in sample 1 and sample 2. Data source: GSOEP (n.d.).

\begin{tabular}{|c|c|c|c|c|}
\hline & & & & \\
\hline & Mean & Std. Dev. & Mean & Std. Dev. \\
\hline 1998 & 0.025 & & 0.026 & \\
\hline 1999 & 0.025 & & 0.026 & \\
\hline 2000 & 0.040 & & 0.043 & \\
\hline 2001 & 0.039 & & 0.042 & \\
\hline 2002 & 0.041 & & 0.043 & \\
\hline 2003 & 0.040 & & 0.042 & \\
\hline 2004 & 0.038 & & 0.040 & \\
\hline 2005 & 0.036 & & 0.038 & \\
\hline 2006 & 0.037 & & 0.040 & \\
\hline 2007 & 0.035 & & 0.038 & \\
\hline 2008 & 0.033 & & 0.035 & \\
\hline 2009 & 0.033 & & 0.036 & \\
\hline 2010 & 0.050 & & 0.053 & \\
\hline 2011 & 0.053 & & 0.052 & \\
\hline 2012 & 0.051 & & 0.052 & \\
\hline 2013 & 0.051 & & 0.050 & \\
\hline 2014 & 0.045 & & 0.045 & \\
\hline 2015 & 0.043 & & 0.045 & \\
\hline $\mathrm{N}$ person-years & 332,537 & & 309,769 & \\
\hline N persons & 44,502 & & 43,106 & \\
\hline
\end{tabular}


Table A2. Educational classification: General vs. vocational education.

\begin{tabular}{|c|c|c|}
\hline ISCED-Level & General & Vocational \\
\hline $\begin{array}{l}\text { 2. Lower \& medium } \\
\text { secondary }\end{array}$ & $\begin{array}{l}\text { Individuals without apprenticeship or other } \\
\text { forms of vocational training, but with a } \\
\text { lower secondary (i.e., Hauptschule) or a } \\
\text { middle school (i.e, Realschule) degree. }\end{array}$ & $\begin{array}{l}\text { Individuals with partially qualifying apprenticeship } \\
\text { or other forms of partially qualifying vocational } \\
\text { training and a lower secondary (i.e., Hauptschule) } \\
\text { or a middle school (i.e, Realschule) degree. }\end{array}$ \\
\hline 3. Higher secondary & $\begin{array}{l}\text { Individuals without apprenticeship or other } \\
\text { forms of vocational training, but with a } \\
\text { high school (i.e., Abitur) degree. }\end{array}$ & $\begin{array}{l}\text { Individuals with fully qualifying apprenticeship or } \\
\text { other forms of fully qualifying vocational training } \\
\text { and a lower secondary (i.e., Hauptschule) or a } \\
\text { middle school (i.e, Realschule) degree. }\end{array}$ \\
\hline \multirow[t]{3}{*}{$\begin{array}{l}\text { 4./5. Post-secondary } \\
\text { \& lower tertiary }\end{array}$} & $\begin{array}{l}\text { Individuals without apprenticeship or other } \\
\text { forms of vocational training, but with a } \\
\text { university of applied science degree. }\end{array}$ & $\begin{array}{l}\text { Individuals with fully qualifying apprenticeship } \\
\text { training or other forms of fully qualifying } \\
\text { vocational training and a high school level degree. }\end{array}$ \\
\hline & & $\begin{array}{l}\text { Individuals with master craftsmen certificates (or } \\
\text { any other technical college degrees) and a lower } \\
\text { secondary (i.e., Hauptschule), a middle school } \\
\text { (i.e, Realschule) or a high school level (i.e., Abitur) } \\
\text { degree. }\end{array}$ \\
\hline & & $\begin{array}{l}\text { Individuals with fully qualifying apprenticeship } \\
\text { training, other forms of fully qualifying vocational } \\
\text { training or with master craftsmen certificates } \\
\text { (or any other technical college degrees) and with a } \\
\text { university of applied science degree. }\end{array}$ \\
\hline 6. Higher tertiary & $\begin{array}{l}\text { Individuals without apprenticeship or other } \\
\text { forms of vocational training, but with a } \\
\text { university degree. }\end{array}$ & $\begin{array}{l}\text { Individuals with fully qualifying apprenticeship } \\
\text { training, other forms of fully qualifying vocational } \\
\text { training or with master craftsmen certificates } \\
\text { (or any other technical college degrees) and with a } \\
\text { university degree. }\end{array}$ \\
\hline
\end{tabular}

Table A3. Relative frequencies: General vs. vocational education. Data source: GSOEP (n.d.).

\begin{tabular}{lrrr}
\hline ISCED-Level & General & Vocational & Total \\
\hline 2. Lower \& medium secondary & 11.67 & 1.13 & 12.80 \\
3. Higher secondary & 1.62 & 51.67 & 53.29 \\
4./5. Post-secondary \& lower tertiary & 2.97 & 16.53 & 19.50 \\
6. Higher tertiary & 9.89 & 4.51 & 14.40 \\
Total & 26.16 & 73.84 & 100.00 \\
\hline
\end{tabular}


1.2. Tables for Main Results (Figures 2, 4, 5, and 6)

Table A4. Employment opportunity over the life course: General versus vocational education by gender. Data source: GSOEP (n.d.).

\begin{tabular}{|c|c|c|}
\hline & $\begin{array}{l}\text { Women } \\
\text { Coef./(se) }\end{array}$ & $\begin{array}{c}\text { Men } \\
\text { Coef./(se) }\end{array}$ \\
\hline $\begin{array}{l}46 \text { age dummies } \\
\text { Type of Education (ref.: General Education) }\end{array}$ & Type of Education (ref.: General Education) & $\checkmark$ \\
\hline Vocational Education & $\begin{array}{l}1.851^{* * *} \\
(0.345)\end{array}$ & $\begin{array}{l}1.060^{*} \\
(0.423)\end{array}$ \\
\hline $\begin{array}{l}46 \text { Age times Vocational Education Dummies } \\
\text { Educational Level (ref.: Lower \& Medium Secondary) }\end{array}$ & Educational Level (ref.: Lower \& Medium Secondary) & $\checkmark$ \\
\hline Higher Secondary & $\begin{array}{l}0.480 * * * \\
(0.054)\end{array}$ & $\begin{array}{l}0.548^{* * *} \\
(0.071)\end{array}$ \\
\hline Post-Secondary/Lower Tertiary & $\begin{array}{l}0.924^{* * *} \\
(0.057)\end{array}$ & $\begin{array}{l}1.244^{* * *} \\
(0.077)\end{array}$ \\
\hline Higher Tertiary & $\begin{array}{l}1.355^{* * *} \\
(0.058)\end{array}$ & $\begin{array}{l}1.713^{* * *} \\
(0.079)\end{array}$ \\
\hline \multicolumn{3}{|l|}{ Cohort groups (ref.: 1919-1945) } \\
\hline $1946-1959$ & $\begin{array}{l}0.694^{* * *} \\
(0.050)\end{array}$ & $\begin{array}{l}0.263^{* * *} \\
(0.052)\end{array}$ \\
\hline 1960-1969 & $\begin{array}{l}0.914^{* * *} \\
(0.058)\end{array}$ & $\begin{array}{c}-0.016 \\
(0.075)\end{array}$ \\
\hline 1970-1979 & $\begin{array}{l}0.833^{* * *} \\
(0.061)\end{array}$ & $\begin{array}{c}-0.126 \\
(0.084)\end{array}$ \\
\hline 1980-1998 & $\begin{array}{l}0.633^{* * *} \\
(0.068)\end{array}$ & $\begin{array}{l}-0.522^{* * *} \\
(0.091)\end{array}$ \\
\hline Unemployment Rate (in \%) & $\begin{array}{l}-0.055^{* * *} \\
(0.005)\end{array}$ & $\begin{array}{l}0.104^{* * *} \\
(0.007)\end{array}$ \\
\hline GDP Growth Rate (in \%) & $\begin{array}{c}-0.010^{*} \\
(0.005)\end{array}$ & $\begin{array}{c}0.010 \\
(0.008)\end{array}$ \\
\hline Growth Rate of Real Disposable Income (in \%) & $\begin{array}{l}-0.019 * * * \\
(0.004)\end{array}$ & $\begin{array}{c}-0.001 \\
(0.007)\end{array}$ \\
\hline Year After the Financial Crisis (2009) & $\begin{array}{c}-0.078 \\
(0.041)\end{array}$ & $\begin{array}{c}0.081 \\
(0.059)\end{array}$ \\
\hline Year Before Cuttings in Unemployment Benefits (2004) & $\begin{array}{l}0.130 * * * \\
(0.025)\end{array}$ & $\begin{array}{c}0.051 \\
(0.036)\end{array}$ \\
\hline German Nationality (ref.: Not German) & $\begin{array}{c}0.151^{*} \\
(0.068)\end{array}$ & $\begin{array}{c}-0.072 \\
(0.085)\end{array}$ \\
\hline Respondent lives in West-Germany (ref.: East-Germany) & $\begin{array}{c}0.053 \\
(0.032)\end{array}$ & $\begin{array}{l}0.774^{* * *} \\
(0.040)\end{array}$ \\
\hline \multicolumn{3}{|c|}{ Parents Level of Education (ref.: No Parent with College Education) } \\
\hline At least one Parent with College Education & $\begin{array}{c}-0.023 \\
(0.046)\end{array}$ & $\begin{array}{c}0.117^{*} \\
(0.055)\end{array}$ \\
\hline Constant & $\begin{array}{c}-2.085^{* * *} \\
(0.156)\end{array}$ & $\begin{array}{c}-1.442^{* * *} \\
(0.191)\end{array}$ \\
\hline Person-years & 174808 & 157729 \\
\hline Number of persons & 23250 & 21252 \\
\hline Degrees of freedom & 110 & 110 \\
\hline Pseudo- $\mathrm{R}^{2}$ & 0.137 & 0.258 \\
\hline
\end{tabular}

Notes: Significance levels: ${ }^{*} \mathrm{p}<0.05,{ }^{* *} \mathrm{p}<0.01,{ }^{* * *} \mathrm{p}<0.001$; standard errors in parentheses; dependent variable: employed or not (0/1). Figure 2 based on these regression results. 
Table A5. Employment opportunity over the life course: General versus vocational education by cohort (women). Data source: GSOEP (n.d.).

\begin{tabular}{|c|c|c|}
\hline & $\begin{array}{l}\text { Cohort } 1 \\
\text { Coef./(se) }\end{array}$ & $\begin{array}{l}\text { Cohort } 2 \\
\text { Coef./(se) }\end{array}$ \\
\hline Age dummies & 25 & 39 \\
\hline \multicolumn{3}{|l|}{ Type of Education (ref.: General Education) } \\
\hline \multirow[t]{2}{*}{ Vocational Education } & -0.140 & 1.188 \\
\hline & $(0.255)$ & $(0.695)$ \\
\hline Age times Vocational Education Dummies & 19 & 39 \\
\hline \multicolumn{3}{|l|}{ Educational Level (ref.: Lower \& Medium Secondary) } \\
\hline \multirow[t]{2}{*}{ Higher Secondary } & $0.624 * * *$ & $0.470 * * *$ \\
\hline & $(0.173)$ & $(0.123)$ \\
\hline \multirow[t]{2}{*}{ Post-Secondary/Lower Tertiary } & $1.050 * * *$ & $0.957 * * *$ \\
\hline & $(0.188)$ & $(0.128)$ \\
\hline \multirow[t]{2}{*}{ Higher Tertiary } & $1.302 * * *$ & $1.595 * * *$ \\
\hline & $(0.154)$ & $(0.123)$ \\
\hline \multirow[t]{2}{*}{ Unemployment Rate (in \%) } & 0.007 & $-0.107^{* * *}$ \\
\hline & $(0.015)$ & $(0.011)$ \\
\hline \multirow[t]{2}{*}{ GDP Growth Rate (in \%) } & $0.065^{* * *}$ & -0.014 \\
\hline & $(0.011)$ & $(0.010)$ \\
\hline \multirow[t]{2}{*}{ Growth Rate of Real Disposable Income (in \%) } & $-0.057 * * *$ & -0.010 \\
\hline & $(0.010)$ & $(0.008)$ \\
\hline \multirow[t]{2}{*}{ Year After the Financial Crisis (2009) } & 0.460 & $-0.204^{* *}$ \\
\hline & $(0.237)$ & $(0.066)$ \\
\hline \multirow[t]{2}{*}{ Year Before Cuttings in Unemployment Benefits (2004) } & $0.617^{* * *}$ & 0.013 \\
\hline & $(0.073)$ & $(0.038)$ \\
\hline \multirow[t]{2}{*}{ German Nationality (ref.: Not German) } & 1.201 & $-0.821^{*}$ \\
\hline & $(1.073)$ & $(0.403)$ \\
\hline \multirow[t]{2}{*}{ Respondent lives in West-Germany (ref.: East-Germany) } & 0.119 & 0.014 \\
\hline & $(0.078)$ & $(0.067)$ \\
\hline \multicolumn{3}{|c|}{ Parents Level of Education (ref.: No Parent with College Education) } \\
\hline \multirow[t]{2}{*}{ At least one Parent with College Education } & 0.072 & 0.033 \\
\hline & $(0.150)$ & $(0.120)$ \\
\hline \multirow[t]{2}{*}{ Constant } & -1.396 & 0.860 \\
\hline & $(1.093)$ & $(0.755)$ \\
\hline Person-years & 28006 & 52077 \\
\hline Number of persons & 3365 & 4870 \\
\hline Degrees of freedom & 52 & 92 \\
\hline Pseudo- $R^{2}$ & 0.190 & 0.093 \\
\hline
\end{tabular}

Notes: Significance levels: ${ }^{*} \mathrm{p}<0.05,{ }^{* *} \mathrm{p}<0.01,{ }^{* *} \mathrm{p}<0.001$; Standard errors in parentheses; dependent variable: Employed or not $(0 / 1)$. Figures $4 a, 4 b, 4 c$, and $4 d$ based on these regression results. 
Table A6. Employment opportunity over the life course: General versus vocational education by cohort (women). Data source: GSOEP (n.d.).

\begin{tabular}{|c|c|c|c|}
\hline & $\begin{array}{l}\text { Cohort } 3 \\
\text { Coef./(se) }\end{array}$ & $\begin{array}{l}\text { Cohort } 4 \\
\text { Coef./(se) }\end{array}$ & $\begin{array}{l}\text { Cohort } 5 \\
\text { Coef./(se) }\end{array}$ \\
\hline Age dummies & 36 & 26 & 16 \\
\hline \multicolumn{4}{|l|}{ Type of Education (ref.: General Education) } \\
\hline \multirow[t]{2}{*}{ Vocational Education } & $1.718^{* *}$ & $2.619 * * *$ & 1.481 \\
\hline & $(0.581)$ & $(0.600)$ & $(0.782)$ \\
\hline Age times Vocational Education Dummies & 36 & 26 & 16 \\
\hline \multicolumn{4}{|l|}{ Educational Level (ref.: Lower \& Medium Secondary) } \\
\hline \multirow[t]{2}{*}{ Higher Secondary } & $0.524 * * *$ & $0.554 * * *$ & $0.488 * * *$ \\
\hline & $(0.107)$ & $(0.101)$ & $(0.107)$ \\
\hline \multirow[t]{2}{*}{ Post-Secondary/Lower Tertiary } & $0.836^{* * *}$ & $0.978 * * *$ & $1.254 * * *$ \\
\hline & $(0.111)$ & $(0.100)$ & $(0.122)$ \\
\hline \multirow[t]{2}{*}{ Higher Tertiary } & $1.191 * * *$ & $1.187^{* * *}$ & $1.663 * * *$ \\
\hline & $(0.118)$ & $(0.101)$ & $(0.139)$ \\
\hline \multirow[t]{2}{*}{ Unemployment Rate (in \%) } & $-0.029 *$ & -0.005 & 0.031 \\
\hline & $(0.013)$ & $(0.016)$ & $(0.022)$ \\
\hline \multirow[t]{2}{*}{ GDP Growth Rate (in \%) } & -0.006 & $-0.080 * * *$ & $-0.236 * * *$ \\
\hline & $(0.011)$ & $(0.019)$ & $(0.040)$ \\
\hline \multirow[t]{2}{*}{ Growth Rate of Real Disposable Income (in \%) } & -0.003 & 0.023 & $0.102 * * *$ \\
\hline & $(0.009)$ & $(0.015)$ & $(0.031)$ \\
\hline \multirow[t]{2}{*}{ Year After the Financial Crisis (2009) } & 0.108 & -0.186 & $-0.760 * * *$ \\
\hline & $(0.083)$ & $(0.105)$ & $(0.167)$ \\
\hline \multirow[t]{2}{*}{ Year Before Cuttings in Unemployment Benefits (2004) } & 0.040 & -0.023 & $-0.286^{*}$ \\
\hline & $(0.044)$ & $(0.063)$ & $(0.143)$ \\
\hline \multirow[t]{2}{*}{ German Nationality (ref.: Not German) } & 0.130 & $0.312 * *$ & $0.388 * *$ \\
\hline & $(0.125)$ & $(0.101)$ & $(0.119)$ \\
\hline \multirow[t]{2}{*}{ Respondent lives in West-Germany (ref.: East-Germany) } & -0.021 & 0.057 & $0.354 * * *$ \\
\hline & $(0.069)$ & $(0.058)$ & $(0.071)$ \\
\hline \multicolumn{4}{|c|}{ Parents Level of Education (ref.: No Parent with College Education) } \\
\hline \multirow[t]{2}{*}{ At least one Parent with College Education } & -0.153 & 0.006 & 0.028 \\
\hline & $(0.087)$ & $(0.069)$ & $(0.083)$ \\
\hline \multirow[t]{2}{*}{ Constant } & $-1.036 * * *$ & $-2.726 * * *$ & $-2.567 * * *$ \\
\hline & $(0.292)$ & $(0.372)$ & $(0.286)$ \\
\hline Person-years & 48657 & 30994 & 13870 \\
\hline Number of persons & 5752 & 5094 & 4135 \\
\hline Degrees of freedom & 86 & 66 & 46 \\
\hline Pseudo- $R^{2}$ & 0.042 & 0.048 & 0.117 \\
\hline
\end{tabular}

Note: Significance levels: ${ }^{*} \mathrm{p}<0.05,{ }^{* *} \mathrm{p}<0.01,{ }^{* * *} \mathrm{p}<0.001$; standard errors in parentheses; dependent variable: Employed or not $(0 / 1)$. Figures $4 \mathrm{e}, 4 \mathrm{f}, 4 \mathrm{~g}, 4 \mathrm{~h}, 4 \mathrm{i}$ and $4 \mathrm{j}$ based on these regression results. 
Table A7. Employment opportunity over the life course: General versus vocational education by cohort (men). Data source: GSOEP (n.d.).

\begin{tabular}{|c|c|c|}
\hline & $\begin{array}{l}\text { Cohort } 1 \\
\text { Coef./(se) }\end{array}$ & $\begin{array}{l}\text { Cohort } 2 \\
\text { Coef./(se) }\end{array}$ \\
\hline \multicolumn{3}{|l|}{ Type of Education (ref.: General Education) } \\
\hline Vocational Education & $\begin{array}{c}0.073 \\
(0.659)\end{array}$ & $\begin{array}{c}0.098 \\
(1.026)\end{array}$ \\
\hline $\begin{array}{l}\text { Age times Vocational Education Dummies } \\
\text { Educational Level (ref.: Lower \& Medium Secondary) }\end{array}$ & 25 & 39 \\
\hline Higher Secondary & $\begin{array}{l}0.640^{* * * *} \\
(0.162)\end{array}$ & $\begin{array}{l}0.982^{* * *} \\
(0.174)\end{array}$ \\
\hline Post-Secondary/Lower Tertiary & $\begin{array}{l}1.346^{* * *} \\
(0.164)\end{array}$ & $\begin{array}{l}1.486 * * * \\
(0.177)\end{array}$ \\
\hline Higher Tertiary & $\begin{array}{l}1.728^{* * *} \\
(0.147)\end{array}$ & $\begin{array}{l}1.948^{* * *} \\
(0.171)\end{array}$ \\
\hline Unemployment Rate (in \%) & $\begin{array}{l}-0.053 * * * \\
(0.015)\end{array}$ & $\begin{array}{l}-0.081 * * * \\
(0.016)\end{array}$ \\
\hline GDP Growth Rate (in \%) & $\begin{array}{r}0.035^{*} \\
(0.014)\end{array}$ & $\begin{array}{c}-0.019 \\
(0.018)\end{array}$ \\
\hline Growth Rate of Real Disposable Income (in \%) & $\begin{array}{c}-0.013 \\
(0.012)\end{array}$ & $\begin{array}{c}0.012 \\
(0.014)\end{array}$ \\
\hline Year After the Financial Crisis (2009) & $\begin{array}{l}0.605^{* *} \\
(0.185)\end{array}$ & $\begin{array}{c}-0.123 \\
(0.096)\end{array}$ \\
\hline Year Before Cuttings in Unemployment Benefits (2004) & $\begin{array}{l}0.351^{* * *} \\
(0.069)\end{array}$ & $\begin{array}{c}-0.041 \\
(0.057)\end{array}$ \\
\hline German Nationality (ref.: Not German) & $\begin{array}{l}-1.882 * * * \\
(0.342)\end{array}$ & $\begin{array}{c}0.185 \\
(0.388)\end{array}$ \\
\hline Respondent lives in West-Germany (ref.: East-Germany) & $\begin{array}{l}0.898^{* * *} \\
(0.081)\end{array}$ & $\begin{array}{l}0.740 * * * \\
(0.078)\end{array}$ \\
\hline Parents Level of Education (ref.: No Parent with College $E$ & & \\
\hline At least one Parent with College Education & $\begin{array}{c}0.246 \\
(0.140)\end{array}$ & $\begin{array}{c}0.208 \\
(0.143)\end{array}$ \\
\hline Constant & $\begin{array}{l}3.919 * * * \\
(0.700)\end{array}$ & $\begin{array}{c}1.034 \\
(0.915)\end{array}$ \\
\hline Person-years & 27163 & 49022 \\
\hline Number of persons & 3232 & 4778 \\
\hline Degrees of freedom & 52 & 92 \\
\hline Pseudo- $R^{2}$ & 0.313 & 0.176 \\
\hline
\end{tabular}

Notes: Significance levels: ${ }^{*} \mathrm{p}<0.05,{ }^{* *} \mathrm{p}<0.01,{ }^{* * *} \mathrm{p}<0.001$; standard errors in parentheses; dependent variable: Employed or not $(0 / 1)$. Figures $5 a, b, c$ and $d$ based on these regression results. 
Table A8. Employment opportunity over the life course: General versus vocational education by cohort (men). Data source: GSOEP (n.d.).

\begin{tabular}{|c|c|c|c|}
\hline & $\begin{array}{l}\text { Cohort } 3 \\
\text { Coef./(se) }\end{array}$ & $\begin{array}{l}\text { Cohort } 4 \\
\text { Coef./(se) }\end{array}$ & $\begin{array}{l}\text { Cohort } 5 \\
\text { Coef./(se) }\end{array}$ \\
\hline $\begin{array}{l}\text { Age dummies } \\
\text { Type of Education (ref.: General Education) }\end{array}$ & 36 & 26 & 16 \\
\hline Vocational Education & $\begin{array}{c}0.601 \\
(0.698)\end{array}$ & $\begin{array}{l}2.183^{* *} \\
(0.839)\end{array}$ & $\begin{array}{l}1.901^{* *} \\
(0.735)\end{array}$ \\
\hline $\begin{array}{l}\text { Age times Vocational Education Dummies } \\
\text { Educational Level (ref.: Lower \& Medium Secondary) }\end{array}$ & 36 & 26 & 16 \\
\hline Higher Secondary & $\begin{array}{l}0.668 * * * \\
(0.152)\end{array}$ & $\begin{array}{c}0.233 \\
(0.142)\end{array}$ & $\begin{array}{c}-0.004 \\
(0.129)\end{array}$ \\
\hline Post-Secondary/Lower Tertiary & $\begin{array}{l}1.470 * * * \\
(0.169)\end{array}$ & $\begin{array}{l}1.157^{* * *} \\
(0.177)\end{array}$ & $\begin{array}{l}0.878 * * * \\
(0.174)\end{array}$ \\
\hline Higher Tertiary & $\begin{array}{l}2.136 * * * \\
(0.187)\end{array}$ & $\begin{array}{l}1.637^{* * *} \\
(0.198)\end{array}$ & $\begin{array}{l}1.247^{* * * *} \\
(0.245)\end{array}$ \\
\hline Unemployment Rate (in \%) & $\begin{array}{c}-0.080 * * * \\
(0.021)\end{array}$ & $\begin{array}{c}-0.099 * * * \\
(0.022)\end{array}$ & $\begin{array}{l}-0.110^{* * *} \\
(0.021)\end{array}$ \\
\hline GDP Growth Rate (in \%) & $\begin{array}{c}0.023 \\
(0.019)\end{array}$ & $\begin{array}{l}0.070^{* *} \\
(0.023)\end{array}$ & $\begin{array}{c}0.018 \\
(0.053)\end{array}$ \\
\hline Growth Rate of Real Disposable Income (in \%) & $\begin{array}{c}-0.001 \\
(0.015)\end{array}$ & $\begin{array}{r}-0.021 \\
(0.019)\end{array}$ & $\begin{array}{r}-0.038 \\
(0.041)\end{array}$ \\
\hline Year After the Financial Crisis (2009) & $\begin{array}{c}0.151 \\
(0.131)\end{array}$ & $\begin{array}{l}0.572^{* *} \\
(0.178)\end{array}$ & $\begin{array}{c}-0.211 \\
(0.213)\end{array}$ \\
\hline Year Before Cuttings in Unemployment Benefits (2004) & $\begin{array}{c}0.013 \\
(0.081)\end{array}$ & $\begin{array}{c}0.017 \\
(0.099)\end{array}$ & $\begin{array}{c}0.020 \\
(0.156)\end{array}$ \\
\hline German Nationality (ref.: Not German) & $\begin{array}{c}-0.116 \\
(0.144)\end{array}$ & $\begin{array}{c}-0.076 \\
(0.140)\end{array}$ & $\begin{array}{c}-0.105 \\
(0.138)\end{array}$ \\
\hline Respondent lives in West-Germany (ref.: East-Germany) & $\begin{array}{l}0.826 * * * \\
(0.093)\end{array}$ & $\begin{array}{l}0.570 * * * \\
(0.091)\end{array}$ & $\begin{array}{l}0.639 * * * \\
(0.097)\end{array}$ \\
\hline Parents Level of Education (ref.: No Parent with College & & & \\
\hline At least one Parent with College Education & $\begin{array}{c}0.120 \\
(0.118)\end{array}$ & $\begin{array}{c}0.033 \\
(0.108)\end{array}$ & $\begin{array}{c}-0.069 \\
(0.104)\end{array}$ \\
\hline Constant & $\begin{array}{l}-2.321^{* * *} \\
(0.408)\end{array}$ & $\begin{array}{c}-1.435^{* * *} \\
(0.366)\end{array}$ & $\begin{array}{l}-1.335^{* * *} \\
(0.308)\end{array}$ \\
\hline Person-years & 45160 & 24377 & 10871 \\
\hline Number of persons & 5463 & 4205 & 3547 \\
\hline Degrees of freedom & 86 & 66 & 46 \\
\hline Pseudo- $\mathrm{R}^{2}$ & 0.112 & 0.150 & 0.252 \\
\hline
\end{tabular}

Notes: Significance levels: ${ }^{*} \mathrm{p}<0.05,{ }^{* *} \mathrm{p}<0.01,{ }^{* * *} \mathrm{p}<0.001$; standard errors in parentheses; dependent variable: Employed or not $(0 / 1)$. Figures $5 e, f, g, h$, $i$ and $j$ based on these regression results. 
Table A9. Health satisfaction over the life course: General versus vocational education for men. Data source: GSOEP (n.d.).

\begin{tabular}{|c|c|}
\hline & $\begin{array}{c}\text { Men } \\
\text { Coef./(se) }\end{array}$ \\
\hline 46 age dummies & $\checkmark$ \\
\hline \multicolumn{2}{|l|}{ Type of education (ref.: General education) } \\
\hline Vocational education & $\begin{array}{c}-0.288 \\
(0.334)\end{array}$ \\
\hline 46 age * vocational education dummies & $\checkmark$ \\
\hline \multicolumn{2}{|l|}{ Educational level (ref.: Lower \& medium secondary) } \\
\hline Higher secondary & $\begin{array}{l}0.303^{* * * *} \\
(0.050)\end{array}$ \\
\hline Post-secondary/lower tertiary & $\begin{array}{l}0.510 * * * \\
(0.052)\end{array}$ \\
\hline Higher tertiary & $\begin{array}{l}0.749 * * * \\
(0.051)\end{array}$ \\
\hline \multicolumn{2}{|l|}{ Cohorts (ref.: 1919-1945) } \\
\hline 1946-1959 & $\begin{array}{c}-0.117^{* *} \\
(0.043)\end{array}$ \\
\hline 1960-1969 & $\begin{array}{l}-0.224^{* * *} \\
(0.048)\end{array}$ \\
\hline 1970-1979 & $\begin{array}{l}-0.324^{* * *} \\
(0.053)\end{array}$ \\
\hline 1980-1998 & $\begin{array}{l}-0.493^{* * *} \\
(0.060)\end{array}$ \\
\hline Unemployment rate (in \%) & $\begin{array}{c}-0.017^{* * *} \\
(0.004)\end{array}$ \\
\hline GDP growth rate (in \%) & $\begin{array}{l}-0.022^{* * *} \\
(0.005)\end{array}$ \\
\hline Growth rate of real disposable income (in \%) & $\begin{array}{l}0.014^{* * *} \\
(0.004)\end{array}$ \\
\hline Year after the financial crisis (2009) & $\begin{array}{c}-0.145^{* * *} \\
(0.033)\end{array}$ \\
\hline Year before Hartz reforms (2004) & $\begin{array}{l}-0.079 * * * \\
(0.021)\end{array}$ \\
\hline German nationality (ref.: Not German) & $\begin{array}{l}-0.238^{* * *} \\
(0.049)\end{array}$ \\
\hline Respondent lives in West Germany (ref.: East Germany) & $\begin{array}{l}0.284^{* * *} \\
(0.028)\end{array}$ \\
\hline \multicolumn{2}{|c|}{ Parents Level of education (ref.: No parent with college education) } \\
\hline At least one parent with college education & $\begin{array}{c}0.078^{*} \\
(0.033)\end{array}$ \\
\hline Constant & $\begin{array}{l}8.796 * * * \\
(0.119)\end{array}$ \\
\hline Person-years & 146548 \\
\hline Number of persons & 20554 \\
\hline Degrees of freedom & 110 \\
\hline Pseudo- $R^{2}$ overall & 0.088 \\
\hline
\end{tabular}

Notes: Significance levels: ${ }^{*} p<0.05,{ }^{* *} p<0.01,{ }^{* * *} p<0.001$; standard errors in parentheses; dependent variable: Health satisfaction. Figure 6 based on these regression results. 


\section{Figures}

a) Individual confounders

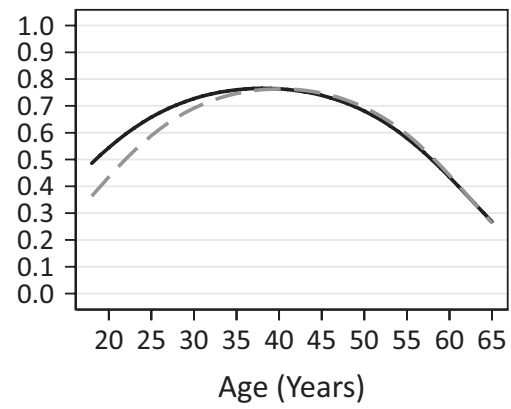

c) + period

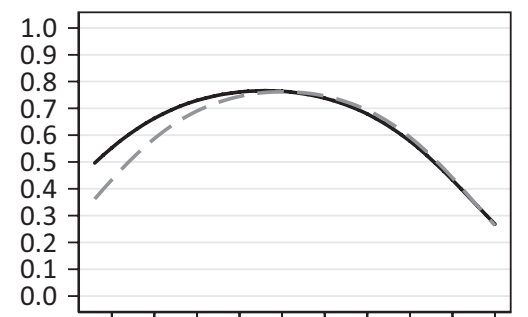

$202530 \quad 3540 \quad 4550556065$ Age (Years)

e) + cohort

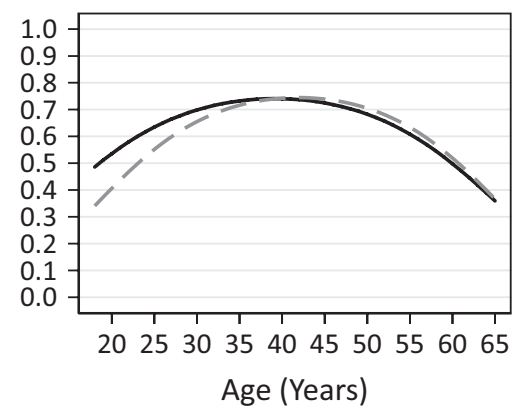

g) + period and cohort

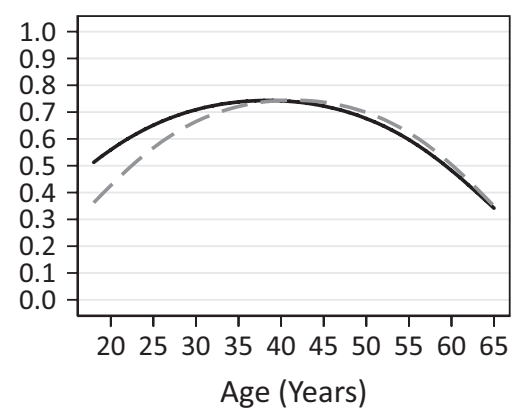

b) Individual confounders

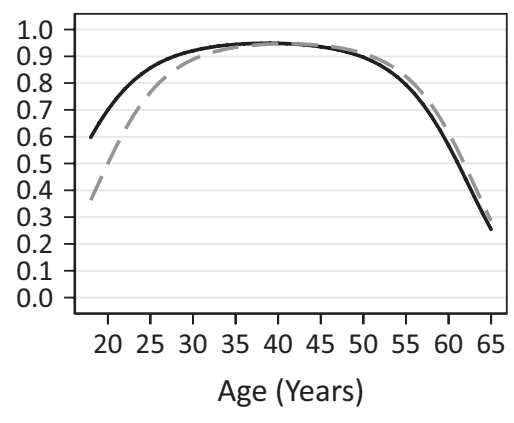

d) + period
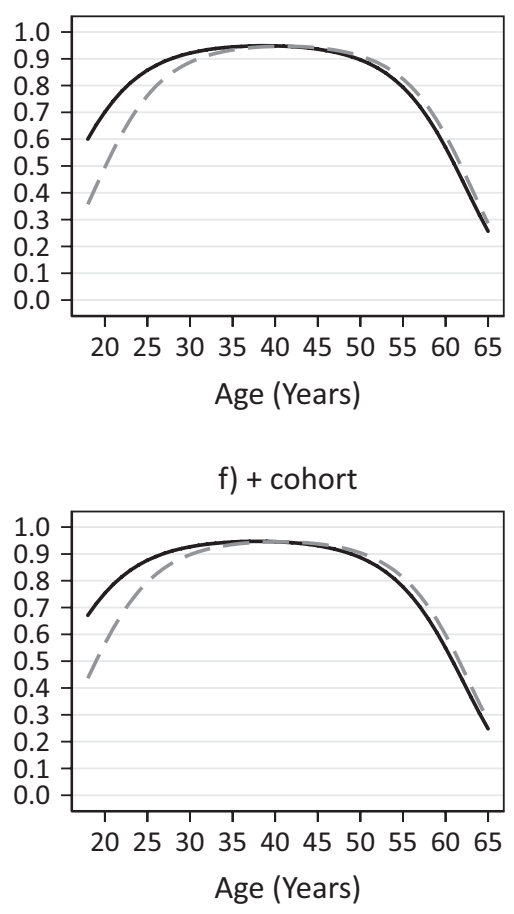

h) + period and cohort

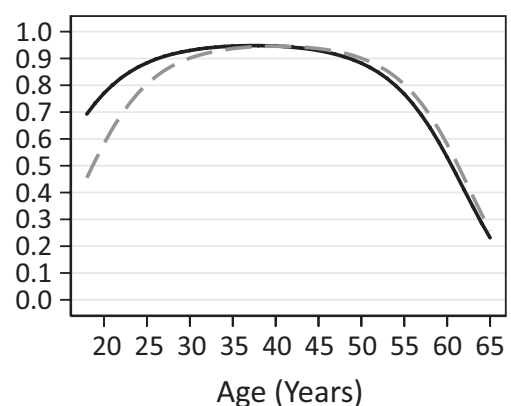

Education

$$
-- \text { gen }
$$

Figure A2. The importance of period and cohort effects for age trajectories for women (left) and men (right). Employment opportunity over the life course: General versus vocational education by gender. Note: Conditional profile plots for women (left) and men (right). Control variables include period effects, cohort effects, German nationality, parental educational background, residence in West Germany, and educational level. $\mathrm{N}$ persons $=44,502$; N person-years $=332,537$. Detailed regression results available upon request. Data source: GSOEP (n.d.). 
a) Profile plot (women)

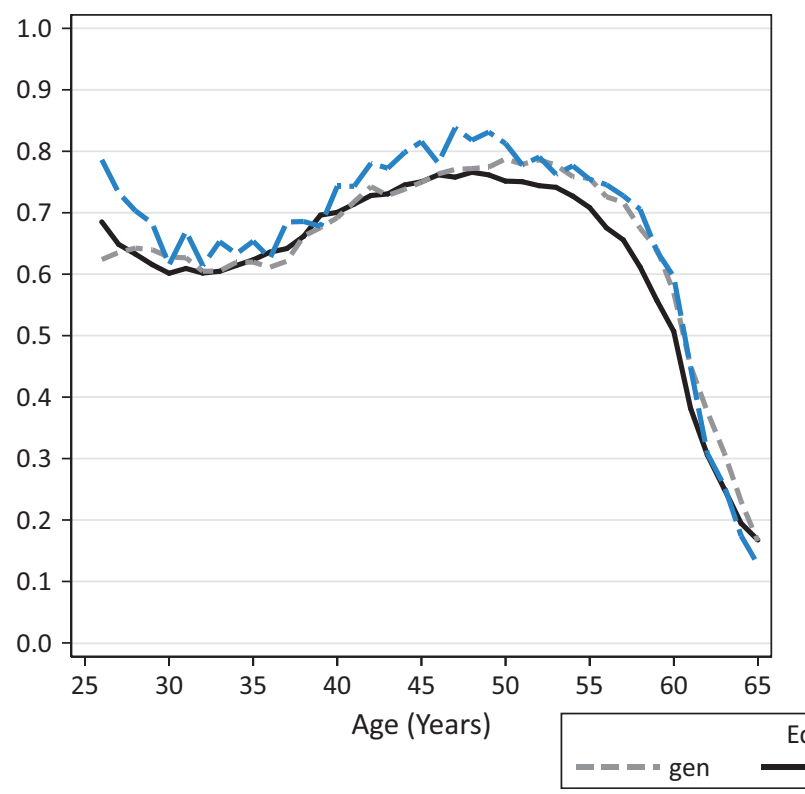

b) Profile plot (men)

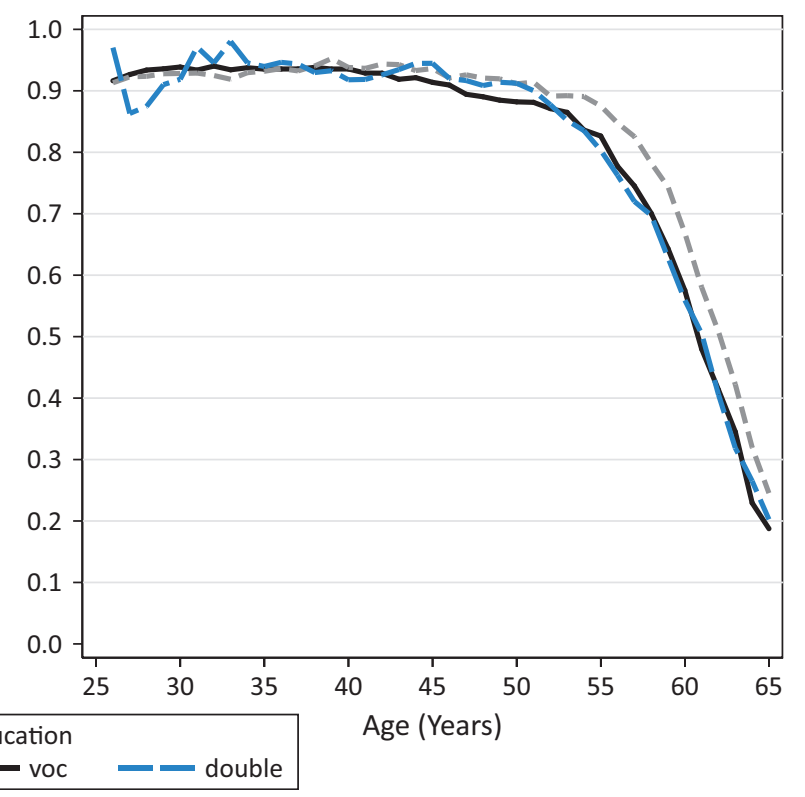

Figure A3. Sensitivity analysis: The role of double qualifications. Employment opportunity over the life course: General, vocational, and double qualifications by gender. Notes: Conditional profile plots for women (left) and conditional profile plots for men (right) estimated by gender-specific non-parametric state probability models on employment probabilities. Control variables include period effects, cohort effects, German nationality, parental educational background, residence in West Germany, and educational level. Detailed regression results available upon request. Data source: GSOEP (n.d.). 
a) Cohort 1: 1919-1945

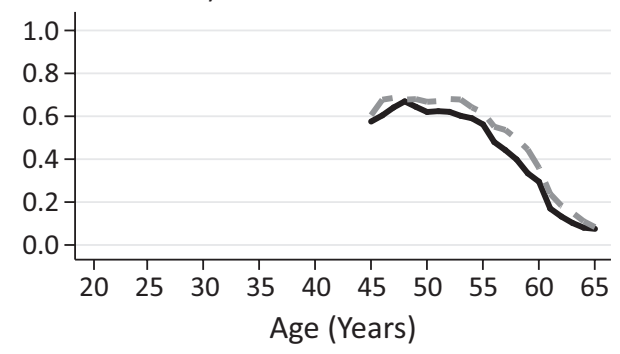

c) Cohort 2: 1946-1959

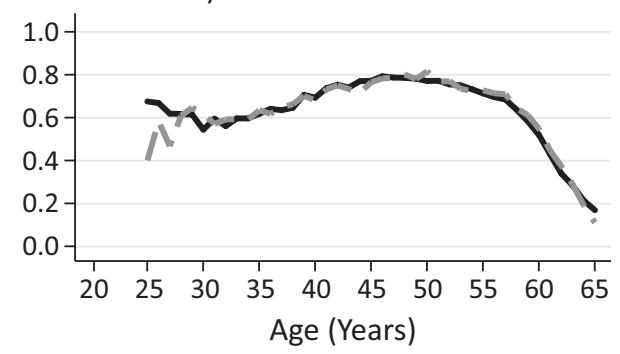

e) Cohort 3: 1960-1969

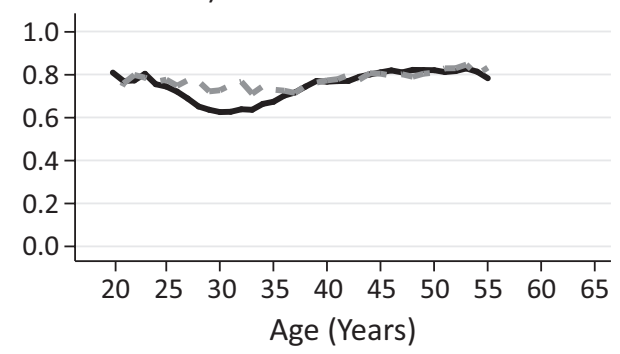

g) Cohort 4: 1970-1979

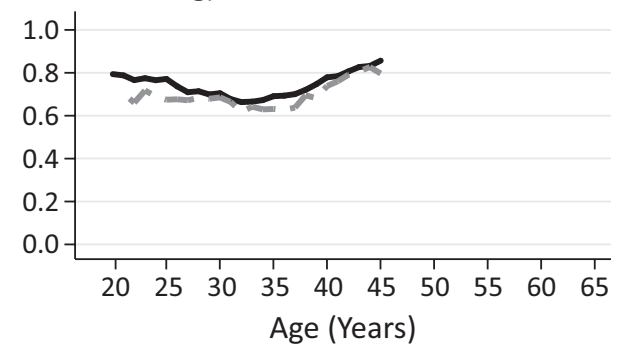

i) Cohort 5: 1980-1998

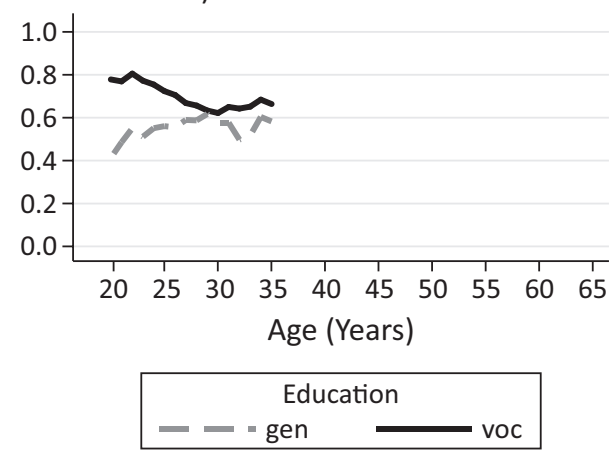

b) Cohort 1: 1919-1945

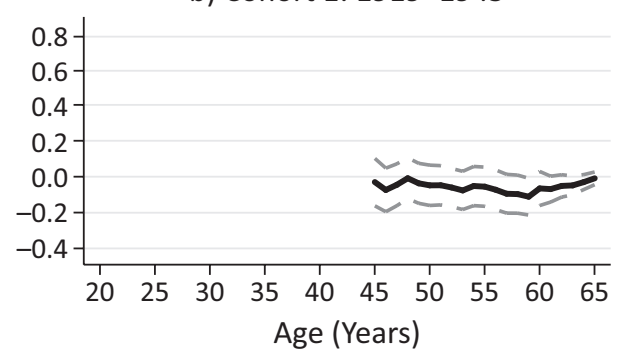

d) Cohort 2: 1946-1959

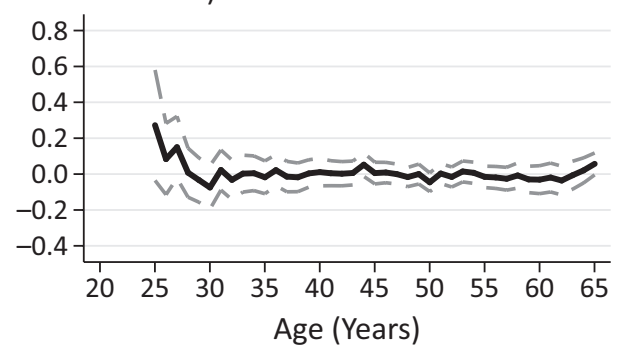

f) Cohort 3: 1960-1969

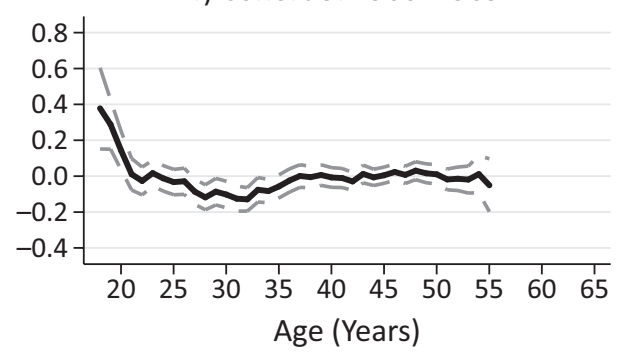

h) Cohort 4: 1970-1979

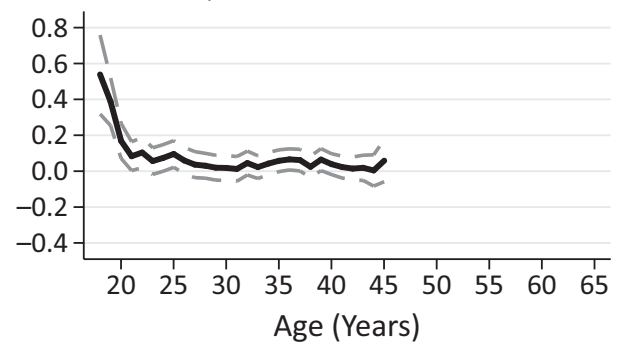

j) Cohort 5: 1980-1998

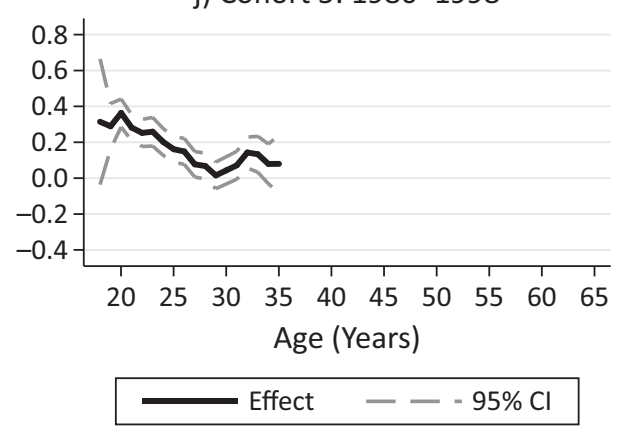

Figure A4. Cohort variation in employment opportunity over the life course: General versus vocational education (women), net of double qualifications (women). Notes: Conditional profile plots (left) and conditional effect plots (right) estimated by cohort-specific non-parametric state probability models of vocational and general education on employment probabilities of women. Control variables include period effects, German nationality, parental educational background, residence in West Germany, and educational level. Detailed regression results available upon request. Data source: GSOEP (n.d.). 
a) Cohort 1: 1919-1945

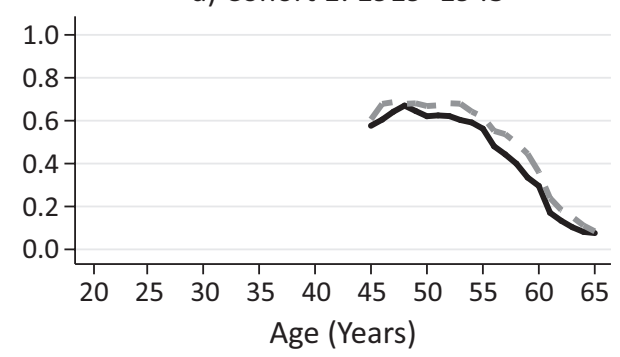

c) Cohort 2: 1946-1959

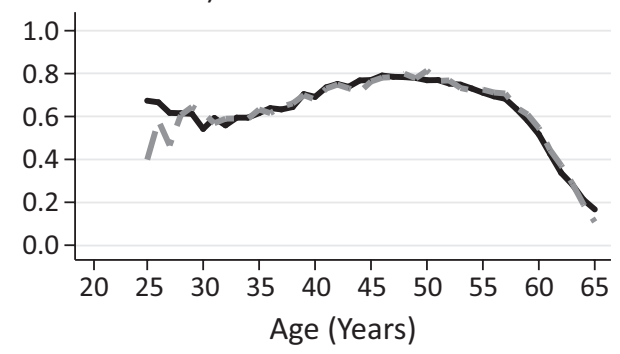

e) Cohort 3: 1960-1969

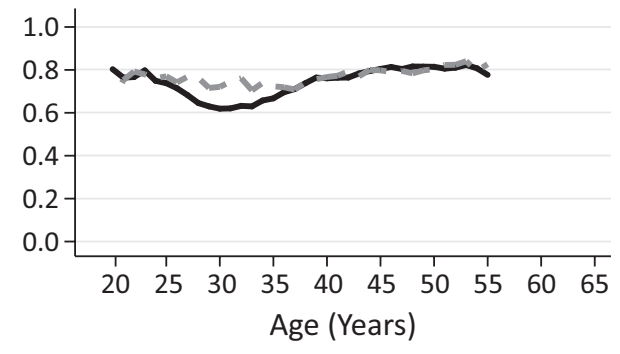

g) Cohort 4: 1970-1979

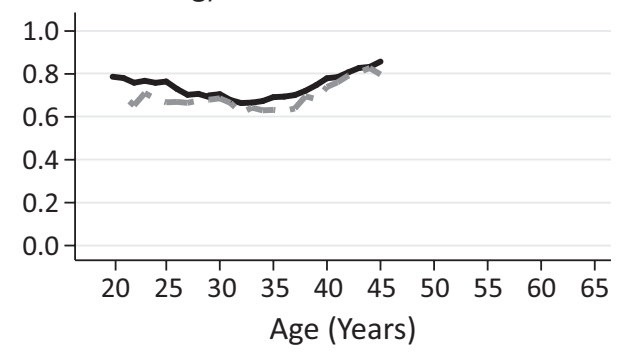

i) Cohort 5: 1980-1998

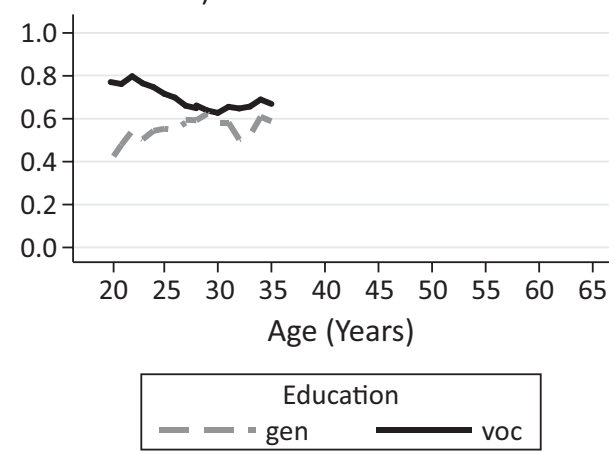

b) Cohort 1: 1919-1945

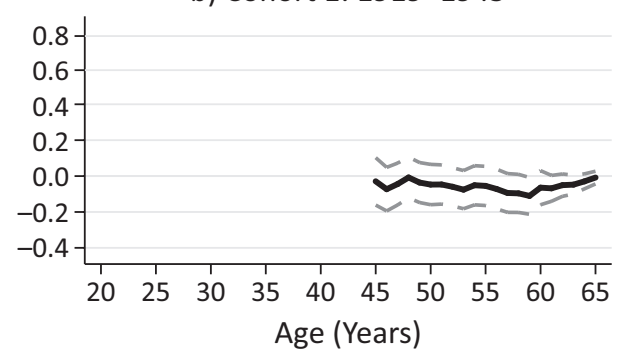

d) Cohort 2: 1946-1959

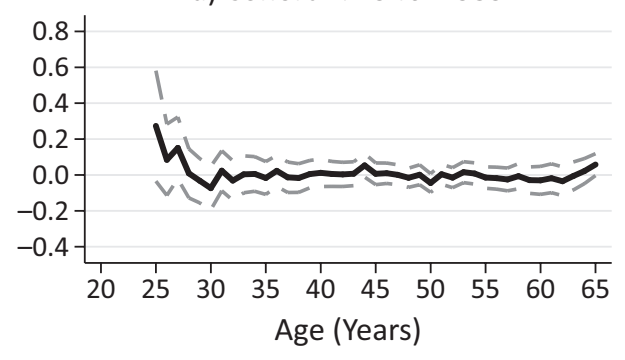

f) Cohort 3: 1960-1969

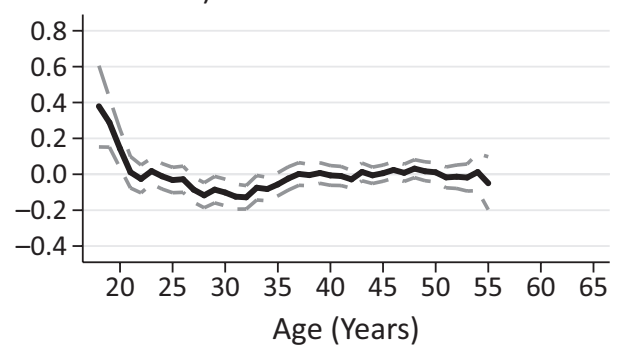

h) Cohort 4: 1970-1979

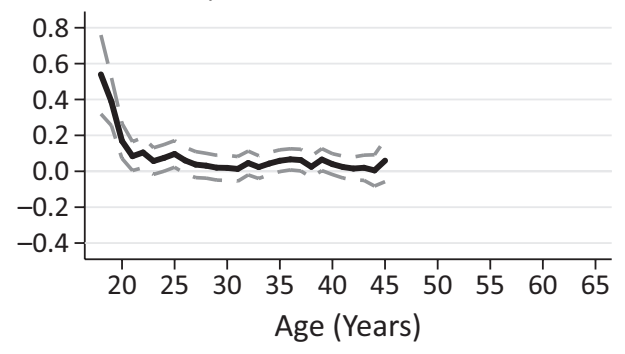

j) Cohort 5: 1980-1998

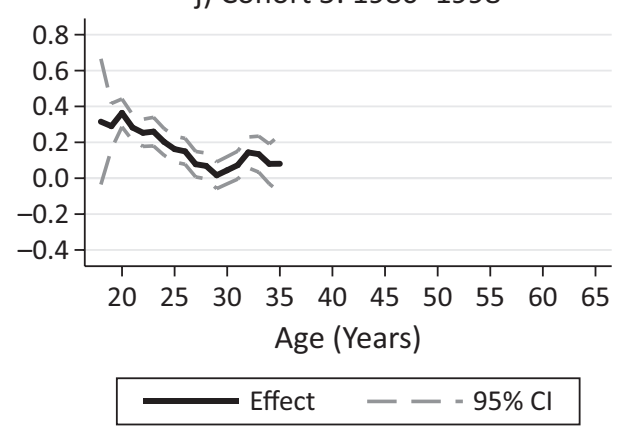

Figure A5. Cohort variation in employment opportunity over the life course: General versus vocational education, net of double qualifications (men). Notes: Conditional profile plots (left) and conditional effect plots (right) estimated by cohortspecific non-parametric state probability models of vocational and general education on employment probabilities of men. Control variables include period effects, German nationality, parental educational background, residence in West Germany, and educational level. Detailed regression results available upon request. Data source: GSOEP (n.d.). 
a) Profile plot (men)

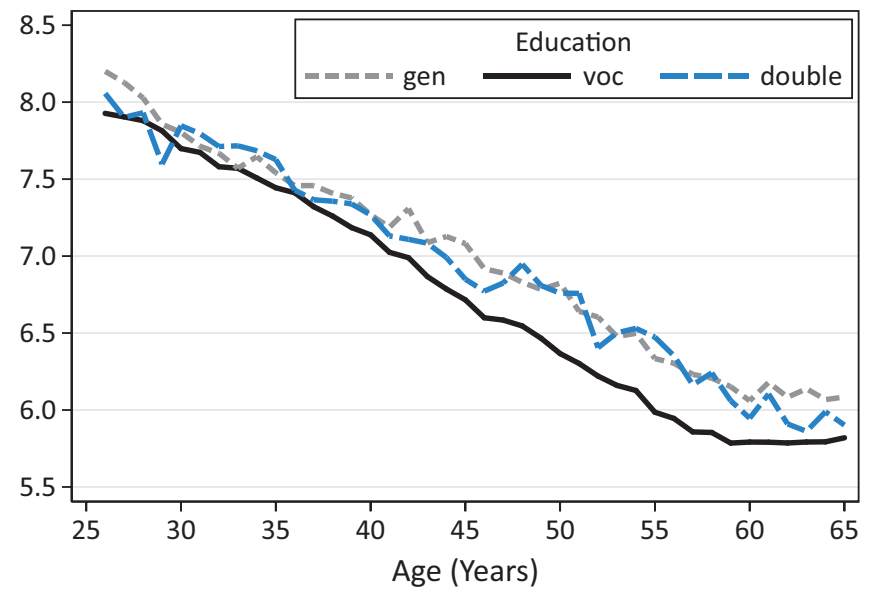

Figure A6. Health satisfaction over the life course: General versus vocational and double qualifications (men). Notes: Conditional profile plot estimated by non-parametric models of vocational and general training on health satisfaction. Control variables include period effects, cohort effects, German nationality, parental educational background, residence in West Germany, and educational level. Detailed regression results available upon request. Data source: GSOEP (n.d.).

a) Total, direct, indirect effect

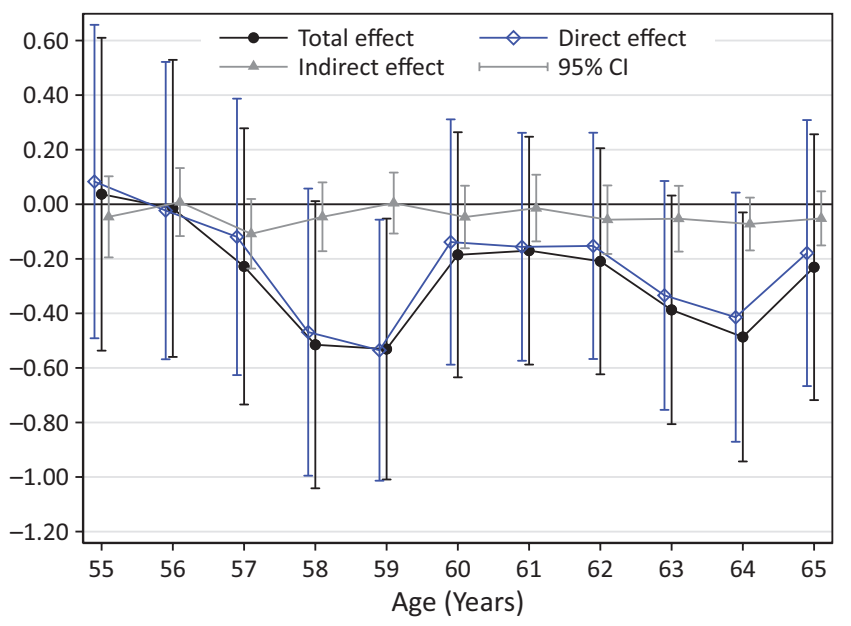

b) Percentage mediated

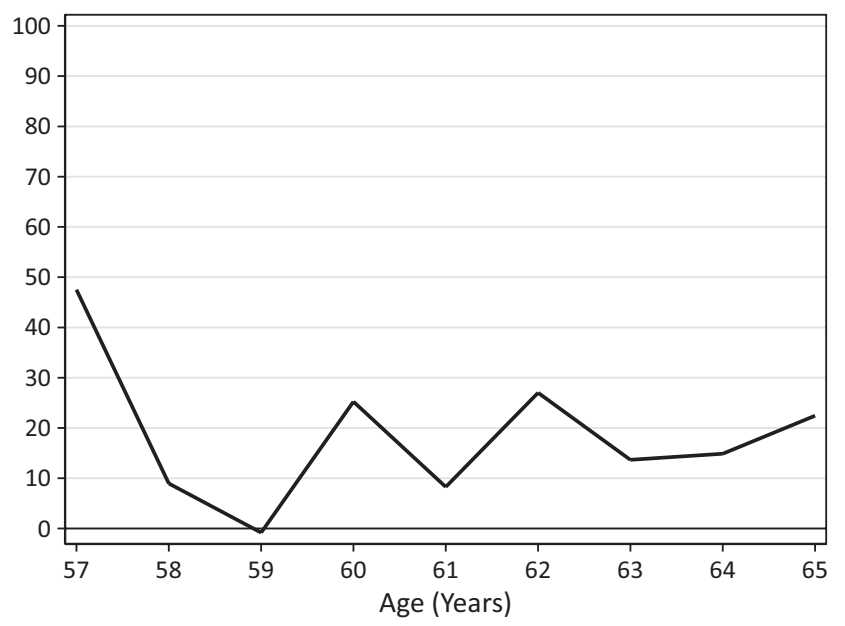

Figure A7. KHB mediation analysis of total, direct, and indirect effects of general versus vocational education on employment probability (not) via health for men (net of double qualifications). Notes: Total and direct effect of general versus vocational education on age-specific employment probabilities. Indirect effects not significant. Figure A7a reports log odds. Mediator variables include nights spent in hospital, doctor visits, disability status, and health satisfaction. Control variables include period effects, cohort effects, German nationality, parental educational background, residence in West Germany, and educational level. Detailed regression results available upon request. Data source: GSOEP (n.d.).

\section{Reference}

German Socio-Economic Panel (n.d.). Data for years 1984-2015, version 32. SOEP. Retrieved from https://www.diw.de/ de/diw_01.c.548849.de/soep_v32.html 